\title{
GEOLOGIA E TECTÔNICA DA FOLHA TOPOGRÁFICA DE CAPÃO BONITO NA ESCALA 1:50.000, SUDESTE DO ESTADO DE SÃO PAULO
}

\author{
GEOLOGY AND TECTONIC OF THE CAPÃO BONITO TOPOGRAPHIC 1:50.000 MAP, \\ SOUTHEAST OF SÃO PAULO STATE
}

\section{Antonio Misson GODOY ${ }^{1}$; Otávio Augusto Ruiz Paccola VIEIRA ${ }^{2}$; Washington Barbosa LEITE JUNIOR $^{1}$; Peter Cristian HACKSPACHER ${ }^{1}$; Suelen Portughesi da MATA ${ }^{3}$, Jonas Menezes ZENERO ${ }^{3}$}

${ }^{1}$ Departamento de Petrologia e Metalogenia- IGCE- UNESP- Univ. Estadual Paulista. Av. 24A, 15151-Bela Vista, CEP. 13 506-900Rio Claro (SP), Brasil. Email: mgodoy@rc.unesp.br, wleite@rc.unesp.br, phack@rc.unesp.br ${ }^{2}$ Pós-Graduação em Geociências- IGCE- UNESP- Univ. Estadual Paulista. Email: otaviovieirageo@ gmail.com ${ }^{3}$ Graduação em Geociências- IGCE- UNESP- Univ. Estadual Paulista. Email: suelen.portughesi@ gmail.com; jonaszenero@gmail.com

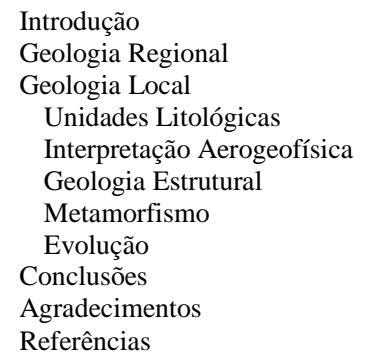

RESUMO - A região da Folha Topográfica de Capão Bonito em escala de 1: 50.000, localiza-se no extremo sul do estado de São Paulo e insere-se na faixa centro-sul do Cinturão Ribeira, na porção norte do Terreno Apiaí. A área envolve rochas da sequência metavulcanossedimentar do Supergrupo Açungui constituídas pelos metassedimentos da Formação Água Clara e do Grupo Votuverava de idade meso- a neoproterozoicas, além de rochas granitoides neoproterozoicas representados por tipos litológicos do Complexo Três Córregos e do Granito Capão Bonito, rochas sedimentares do Grupo Itararé, intrusivas básicas associadas ao Magmatismo Serra Geral e sedimentos recentes quaternários. A evolução geológica é determinada pelo arranjo tectônico-metamórfico neoproterozoico, que é definida por três fases de deformacionais. Os dois eventos iniciais são relacionados a uma tectônica tangenciais, ligados à fase colisional, e consequente espessamento de massas crustais e a colocação e deformação das rochas sin- colisionais do Complexo Três Córregos. A deformação posterior é marcada por uma tectônica transcorrente/transpressiva em que ocorre associada à ascensão magmática tardia e a atual estruturação alongada do granito pós-colisional Capão Bonito. O metamorfismo regional progressivo é do tipo Barroviano, com rochas em fácies xisto verde alto, com ocorrências locais de metamorfismo de contato e o dinâmico que apresentam natureza retrometamórfica.

Palavras-chave: geologia, estrutural, mapeamento, Capão Bonito.

\begin{abstract}
The 1: 50.000 Capão Bonito Topographic Map is situated at the southern end of São Paulo state, in the south-central Ribeira Belt, in the northern portion of the Apiaí Terrain. The area involves rocks from the Açungui Supergroup metavolcanicsedimentary sequence, constituted by the Água Clara Formation and the Votuverava Group metassediments of Meso and Neoproterozoic age. Três Córregos Complex and Capão Bonito Neoproterozoic Granite are also present. Itararé Group sedimentary rocks, associated with Serra Geral basic magmatism also occur covered by recent quaternary sediments. The geological evolution is determined by the Neoproterozoic tectonic-metamorphic arrangement, defined by three deformation phases. The two initial events are related to a tangential tectonic linked to the collisional phase, consequent thickening of crustal masses and the emplacement and deformation of the Três Córregos syn collisional Complex. The posterior deformation is marked by a transcurrent/transpressive tectonics which occurs associated with the late magmatic ascent and the present elongated structuring of the Capão Bonito Granite post-collisional rocks. The progressive regional metamorphism is of Barrovian type, with rocks in high green schist facies; local occurrences of contact metamorphism; and the dynamic event that represents a retro metamorphic character.
\end{abstract}

Keywords: geology, structural, mapping, Capão Bonito.

\section{INTRODUÇÃO}

A área geológica da Folha Topográfica de Capão Bonito (SG-22-X-B-III-1) em escala 1:50.000, do Instituto Brasileiro de Geografia e Estatística - IBGE, encontra-se localizada a sudoeste da cidade de São Paulo, limitada pelas coordenadas $23^{\circ} 45^{\prime}$ e $23^{\circ} 00^{\prime}$ de latitude sul e $47^{\circ} 15^{\prime}$ e $47^{\circ} 00^{\prime}$ de longitude oeste.

A parte sul da área da folha topográfica é a mais carente em termos de conhecimento geológico, resultado, em grande parte, devido a cobertura de reservas florestais do Parque Estadual de Intervales. 
A região encontra-se inicialmente definida nos mapas geológicos do Estado de São Paulo, do Instituto Geográfico e Geológico, em escala 1: 1.000 .000 (1963, 1974). Os primeiros mapeamentos específicos das rochas da Folha Capão Bonito em escala 1:100.000, foram elaborados em 1968 para o Departamento Nacional de Produção Mineral, e, em seguida, a região encontra-se caracterizada no Mapa Geológico do Estado de São Paulo, editado pelo Instituto Geográfico e Geológico em escala 1: 1.000.000.

Melcher et al., (1971, 1973), a partir do Projeto Ribeira patrocinado pelo Departamento Nacional da Produção Mineral, publica os dados a Folha Topográfica de Capão Bonito (Bettencourt et al., 1971) e Guapiara (Cordani et al., 1971), em escala 1: 100.000.

Algarte et al. (1973), no trabalho de pesquisa mineral realizado em 1972/1974, pelo convênio DNPM/CPRM em escala 1:10.000, contemplou as áreas dos municípios de Capão Bonito, Guapiara, Apiaí, Iporanga, Itapeva, Ribeirão Branco e Itararé.

Estes materiais geológicos encontram-se sistematizados no mapa geológico de integrações do estado de São Paulo em escala 1:500.000, elaborados pelo Instituto de Pesquisa Tecnológica - IPT (Bistrichi et al., 1981; Almeida et al., 1981; Hasui et al. 1981).

Trabalhos específicos voltados para atividades de prospecção pelo Departamento Nacional de Pesquisa Mineral foram obtidos a partir de mapeamento geológico da Folha Capão Bonito em escala 1: 50.000 (Chiodi Filho et al., 1983) e para o Catálogo de Rochas Ornamentais do Estado de São Paulo (IPT, 1990), a partir da caracterização de aspectos ornamentais do Granito Capão Bonito.

A integração mais atualizada encontra-se no mapa geológico em 1: 750.000, elaborado pela Companhia de Pesquisa de Recursos Minerais (Perrotta et al., 2005).

A evolução geológica do Domínio Apiaí, parte da identificação e descrição das diversas sequências de rochas metassedimentares, separadas por zonas de cisalhamento pode ser vista em Soares, 1987, 1988; Campanha et al., 1987; Campanha, 1991; Basei et al., 1992; Reis Neto, 1994; Siga Junior, 1995; Fassbinder, 1996; Campanha \& Sadowski, 1999.

Os aspectos do contexto e da compreensão estrutural, a partir do estudo dos lineamentos macroestruturais em Soares, 1987, 1988; Campanha et al., 1987; Fiori, 1990, 1992; Campanha, 1991, 2002; Basei et al., 1992; Basei et al., 2003; Reis Neto, 1994; Siga Junior,1995; Fassbinder, 1996; Campanha \& Sadowski, 1999; Hackspacher \& Godoy, 1999; Faleiros, 2008; Faleiros et al., 2010, 2011; Vieira, 2017, Vieira et al., 2018.

Reconhece-se muitas vezes uma superposição de lineamentos mesozoicos, orientados na direção principal NW-SE, marcando importantes feições morfoestruturais regionais, que são resultantes da estruturação do Arco de Ponta Grossa, que representa uma estrutura tectônica de soerguimento com eixo orientado a NW.

A estes lineamentos encontram-se associados enxames de diques e são denominados por Lineamento Guapiara, Lineamento São Jerônimo-Curiúva, Lineamento Rio Alonzo e Lineamento Rio Piquiri (Spinelli \& Gomes, 2008).

Trabalhos específicos sobre o Granito Capão Bonito envolvem estudos geofísicos que foram realizados por Souza Júnior \& Porsani (2003) e Porsani et al. (2005) e que permitiram subsidiar uma melhor cubagem da jazida de rochas ornamentais "Soimbras".

Os aspectos da geologia, petrografia, estrutural e geoquímica das rochas do maciço, que são comercializadas sob a denominação de Granito Vermelho Capão Bonito, resultam de Bolonini \& Godoy (2010, 2011); Bolonini (2011); Bolonini et al. (2011) e a geocronologia deve-se ao trabalho de Leite (2003), que apresenta através do método U-Pb em zircão a idade de $564 \pm 8 \mathrm{Ma}$.

A região é constituída pelas rochas epimetamórficas meso a neoproterozoicas da sequência metavulcanossedimentar do Supergrupo Açungui, Formação Agua Clara e Grupo Votuverava, pelas rochas intrusivas graníticas neoproterozoicas do Complexo Três Córregos e do Granito Capão Bonito, além de rochas sedimentares do Grupo Itararé, de rochas básicas associadas ao magmatismo Serra Geral e de sedimentos recentes.

O estudo resultou inicialmente da integração de mapeamentos geológicos em escala 1:25.000, executados parcialmente em partes da folha topográfica, por trabalho de campo da UNESP Rio Claro em 2009; de mapeamentos geológicos 
em escala 1: 25.000 de Bolonini (2011); Bolonini \& Godoy (2010, 2011); Chiodi Filho et al. (1983); Campanha (1991, 2002); visto na integração da figura 4B.
As pesquisas evoluíram para mapeamento completo da área da folha topográfica, além de trabalhos que consistiram na homogeneização e integração de todas as unidades geológicas.

\section{GEOLOGIA REGIONAL}

A área insere-se na Província Mantiqueira Central (Almeida, 1967, 1981a; Hasui \& Oliveira, 1984; Heilbron et al., 2004), na faixa sul do Cinturão Ribeira (Almeida et al.,1977; Cordani et al., 1973; Hasui et al., 1978; Hasui, 2010, 2012) ou no Cinturão de Dobramentos Sudeste (Cordani et al., 2000)

O Cinturão Ribeira é caracterizado na área pelo Terreno Apiaí (Hasui, 2010, 2012) que é separado por zonas de cisalhamento transcorrentes destrais (Campanha, 1991, 2002; Campanha \& Sadowski, 1999; Heilbron et al., 2004; Faleiros, 2008; Faleiros et al., 2010, 2011; Santos et al., 2015). A partir do trabalho de Hennies et al. (1967), surgiram as primeiras ideias de compartimentação tectônica do Pré-Cambriano no Estado de São Paulo, através de falhamentos transcorrentes. Essas grandes zonas de cisalhamento compartimentam a região em grandes blocos tectônicos delimitados por falhas, $\mathrm{o}$ que colocou unidades de idades e profundidades diferentes lado a lado.

O Terreno Apiaí consiste em sequências supracrustais de baixo a médio grau metamórfico, designadas como Grupo Açungui (Almeida, 1957; Petri \& Suguio, 1969; Fiori, 1990; Campanha 1991; Campanha \& Sadowski, 1999), e posteriormente proposto como Supergrupo Açungui (Campanha, 1991; Campanha \& Sadowski, 1999) de idade mesoproterozoica a ediacarana por Tassinari et al. (1990) e Fiori (1992, 1994) e teve a divisão estratigráfica na área proposta em três unidades litotectônicas principais denominadas de Formação Água Clara e grupos Votuverava e Itaiacoca, identificadas na figuras 1A, B.

Datações minerais isotópicas U-Pb disponíveis por Tassinari (1988), Hackspacher et al. (2000), Dantas et al., 1999, 2000; Weber et al. (2004); Passarelli et al. (2004); Campanha et al. (2008, 2015); Siga Junior et al. (2009, 2011) indicam que o Terreno Apiaí foi formado pela amalgamação de unidades supracrustais cujas idades variam de Callimiano (1500-1400 Ma: Formação Água Clara e Grupo Votuverava), a Toniano (1000-900 Ma: parte do Grupo Itaiacoca) e a Ediacarano (630-580 Ma: parte do Grupo Itaiacoca).
A Formação Água Clara é subdividida em dois termos informais principais: (I) Unidade de Xistos, dominada por litotipos silicáticos como mica xisto, quartzo-mica xisto e xisto carbonático apontando para origem em ambiente marinho profundo; e (II) Unidade Carbonática, composta por rochas calciossilicáticas e mármore calcítico puro a impuro, originada em domínio de plataforma continental rasa (Fiori, 1990, 1994; Kops, 1994; Frascá et al., 1990). Destas unidades reconheceu-se em campo um pacote de filitos sericíticos a quartzosos com intercalações de metacalcários (mármore, metacalcário e metacalciossilicatadas) e lentes de anfibolitos (Vieira, 2017).

O Grupo Votuverava é subdividido em cinco formações: Perau, Rubuquara, Nhunguara, Piririca e Ribeirão das Pedras, além de duas unidades informais: micaxisto e granada micaxisto, diferenciadas apenas por metamorfismo em níveis crustais distintos (Perrotta, 1996). É limitado, a sul, pela Zona de Cisalhamento Lancinha e, a norte, pelas zonas de cisalhamento Ribeira, Agudos Grandes e Figueira (Campanha, 1991). A unidade é composta por uma sequência metavulcanossedimentar, com magmatismo básico associado, na forma de lentes intercaladas de metabasitos (anfibólio xisto, anfibolito) concordantes com as estruturas primárias (Petri \& Suguio, 1969; Campanha et al., 1987, 2015; Campanha \& Sadowski, 1999).

$\mathrm{Na}$ área da folha predominam pacotes de quartzitos, xistos, além de expressivas lentes de actinolita xistos e anfibolitos (Vieira, 2017; Vieira et al., 2018).

A evolução do Terreno Apiaí remonta às sequências metassedimentares de idades meso- e neoproterozoica que foram acrescidas como um terreno durante o Neoproterozoico (Faleiros, 2008). Acredita-se que as sequências mesoproterozoicas desses terrenos registrem uma história metamórfica e de deformação anterior a instalação das bacias neoproterozoicas, apresentando em geral um metamorfismo na fácies xisto verde médio a anfibolito (Heilbron et al., 1995; 2004, Faleiros, 2008, Campanha et al., 2015).

O padrão deformacional dominante nas rochas 
supracrustais neoproterozoicas do Terreno Apiaí se deu inicialmente por etapa orogenética (Heilbron et al., 2004), com uma evolução marcada pela superposição de eventos. O primeiro evento $D_{n}$ é relacionado a uma tectônica de cavalgamento, que gerou generalizada aloctónia dos tipos litológicos, acompanhado de estruturas geneticamente associadas, tais como falhas de cavalgamentos, dobras e a foliação $S_{n}$, enquanto a foliação $S_{n+1}$ seria gerada no evento $\mathrm{D}_{\mathrm{n}+1}$ também de cavalgamento, ambas progressivas. São identificadas dobras fechadas a isoclinais, centimétricas e de flanco rompido $S_{n+1}$, desenvolvidas sobre a foliação $S_{n}$ (Weber et al, 2004; Vieira, 2017, Vieira et al., 2018a). Os dobramentos recumbentes mostram vergência para NW, constituindo o chamado Sistema de Cavalgamento Açungui (Fiori, 1994).

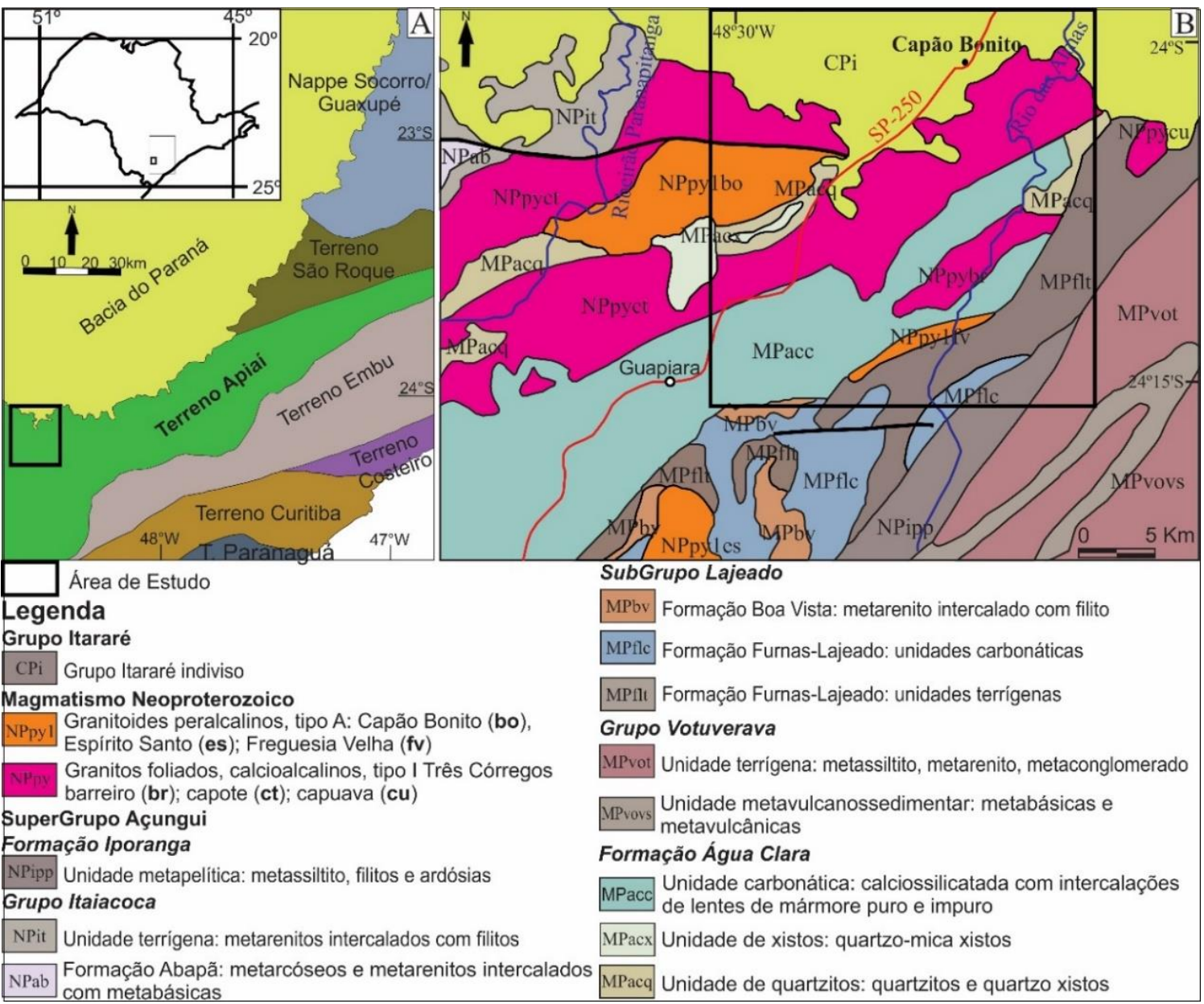

Figura 1 - Mapa do Pré-Cambriano do estado de São Paulo com a localização da área em relação à disposição das principais unidades litoestratigráficas. Mod. Perrotta et al. (2005).

Superpondo-se a estas estruturas, ocorre um evento $\mathrm{D}_{\mathrm{n}+2}$, ligado à fase colisional final caracterizada por intenso escape lateral de direção NE-SW, ligado a uma tectônica transcorrente/transpressiva (Hackspacher et al., 2000; Vieira, 2017). Esse evento é responsável pelo dobramento das estruturas pré-formadas, como o acamamento reliquiar, o bandamento composicional e as foliações $S_{n}$ e $S_{n+1}$. As dobras são abertas a isoclinais, com plano axial NE-SW e inclinação superior a $60^{\circ}$, e pode ser verificado em diversas escalas, coincidentes com a foliação $S_{n+2}$ (Fiori, 1994). Esse evento foi denominado como Sistema de Dobramentos Apiaí (Fiori, 1992).

Nas proximidades das zonas de cisalhamento é observada a foliação $S_{n+2}$ paralela à foliação milonítica $\mathrm{S}_{\mathrm{m}}$, desenvolvida a partir de movimentações diferenciais dos blocos em condições de baixa temperatura (Campanha, 1991, 2002 e Faleiros, 2008). A essa tectônica se deve a presente configuração dos blocos e a colocação lado a lado de sequências com fácies metamórficas distintas (Hackspacher et al., 2000).

O magmatismo ácido é marcado na área pela presença das rochas granitóides neoproterozoicas sin-colisionais do Complexo Três Córregos (Prazeres Filho et al., 2003) e pela granitogênese pós-orogênica a anorogênica do Granito Capão Bonito em níveis crustais mais rasos, representando o início da extensão crustal, 
associada à estruturação da Bacia do Paraná (Godoy, 1989; 2003), magmatismo este associado à formação do Arco Magmático Rio Negro (Heilbron et al., 2004).

$\mathrm{O}$ estudo dos granitoides pós-orogênicos a anorogênicos da Faixa de Dobramento Ribeira foi inicialmente proposto por Hasui et al. (1978) e Janasi \& Ulbrich (1992), que individualizaram os inúmeros corpos graníticos pós-tectônicos do estado de São Paulo.

As rochas do Complexo Três Córregos são constituídas por um batólito de caráter tardi- a póstectônico, com alongamento na direção NE-SW e que é composto predominantemente por biotitahornblenda monzogranito, biotita-hornblendaquartzo monzonito e granodiorito, com textura porfirítica e megacristais de feldspato potássico, deformados ou não (Fuck, 1967).

São granitoides do Tipo I, com tendência cálcioalcalina de alto $\mathrm{K}$, gerados em um ambiente de margem ativa entre 630 e $605 \mathrm{Ma}$ (idades U-Pb em zircão) (Guimarães, 2000, Prazeres Filho et al., 2003). Segundo Prazeres Filho et al. (2003) e Bolonini \& Godoy (2013), o período pós-colisional anorogênico é marcado pela intrusão de plútons graníticos rasos e inclui o corpo do Granito Capão Bonito.

O Granito Capão Bonito de natureza pósorogênico a anorogênico constituem em parte o Cinturão Granitoide Rapakivi Itu definido por Vlach et al. (1990) ou a Província Rapakivi Itu por Wernick et al. (1993; 1997, 2000).
Durante o evento magmático neoproterozoico ocorreria um processo colisional (NW-SE), seguido aos alojamentos do magmatismo cálcioalcalino a alcalino pós-orogênico a anorogênico (Godoy, 1989) e, ao final, um processo de escape tectônico com reativações de inúmeras zonas de cisalhamento transcorrentes que seriam responsáve.is pela movimentação e posicionamento final dos blocos crustais.

Trabalho específico de geoquímica e geocronologia de Leite (2003) para a área do magmatismo pós-orogênico que ocorre associado às rochas sin-colisionais do Batólito Granítico Agudos Grandes, permite a definição de dois conjuntos de granitos apresentando afinidades geoquímicas com os granitos do tipo A.

Um conjunto é caracterizado na área pelo plúton Capão Bonito que apresenta para as rochas a idade de $585 \mathrm{Ma}$ através do método U-Pb e valores fortemente negativos de $\boldsymbol{\varepsilon}_{\mathbf{N d}}{ }^{(\mathbf{t})}(-16)$, e altos valores ${ }^{87} \mathrm{Sr} /{ }^{86} \mathrm{Sr}$ inicial (entre 0,715 a 0,717 ), consistentes com a participação importante de uma fonte crustal antiga empobrecida e/ou evoluída para o magma parental.

Quimicamente, as rochas do Maciço Capão Bonito, apresentam características de granito tipo-I anarogênicos como propostos por Leite (2003) e Leite et al. (2007) encontram-se reforçadas nos trabalhos de Bolonini et al. (2011) e Salazar et al. (2011). Além destes trabalhos ressalta-se os de cunho geofísico realizados por Souza Júnior \& Porsani (2003) e Porsani et al. (2005).

\section{GEOLOGIA LOCAL}

A nomenclatura e classificação mais utilizada é a proposta pela IUGS (International Union Geological Sciences), publicada por Streckeisen (1979) e definindo "carbonatito como rocha ígnea com sílica $<10 \%$ e que contém mais de $50 \%$ de minerais magmáticos carbonatíticos primários". Estas recomendações foram adotadas também por Woolley \& Kempe (1989) e Le Maitre (2002). A região é constituída pelas unidades estratigráficas com evolução no Mesoe Neoproterozoico do Supergrupo Açungui representado por uma sequência metavulcanossedimentar e raras intrusivas básicas da Formação Água Clara e Grupos Votuverava, rochas granitóides neoproterozoicas do Complexo Três Córregos, Granito Capão Bonito e rochas fanerozóicas do Grupo Itararé, magmatismo básico associado a Formação Serra Geral e sedimentos do Quaternário (Figura 2).

A estratigrafia da área da Folha Topográfica de Capão Bonito é baseada nos trabalhos regionais de Chiodi Filho et al. (1983) e Campanha (2002), com modificações propostas por Faleiros (2008), Vieira (2017) e Vieira et al. (2018), considerando-se as litologias mapeadas, os dados estruturais e a evolução metamórfica.

\section{Unidades Litológicas}

A Formação Água Clara apresenta abrangência a sul da Zona de Cisalhamento Quarenta Oitava e é caracterizada por uma sucessão de litotipos predominantemente clásticos e químicos, além actinolita xistos e raras rochas metabásicas. A norte, ocorre o contato com os granitoides do Complexo Três Córregos. 


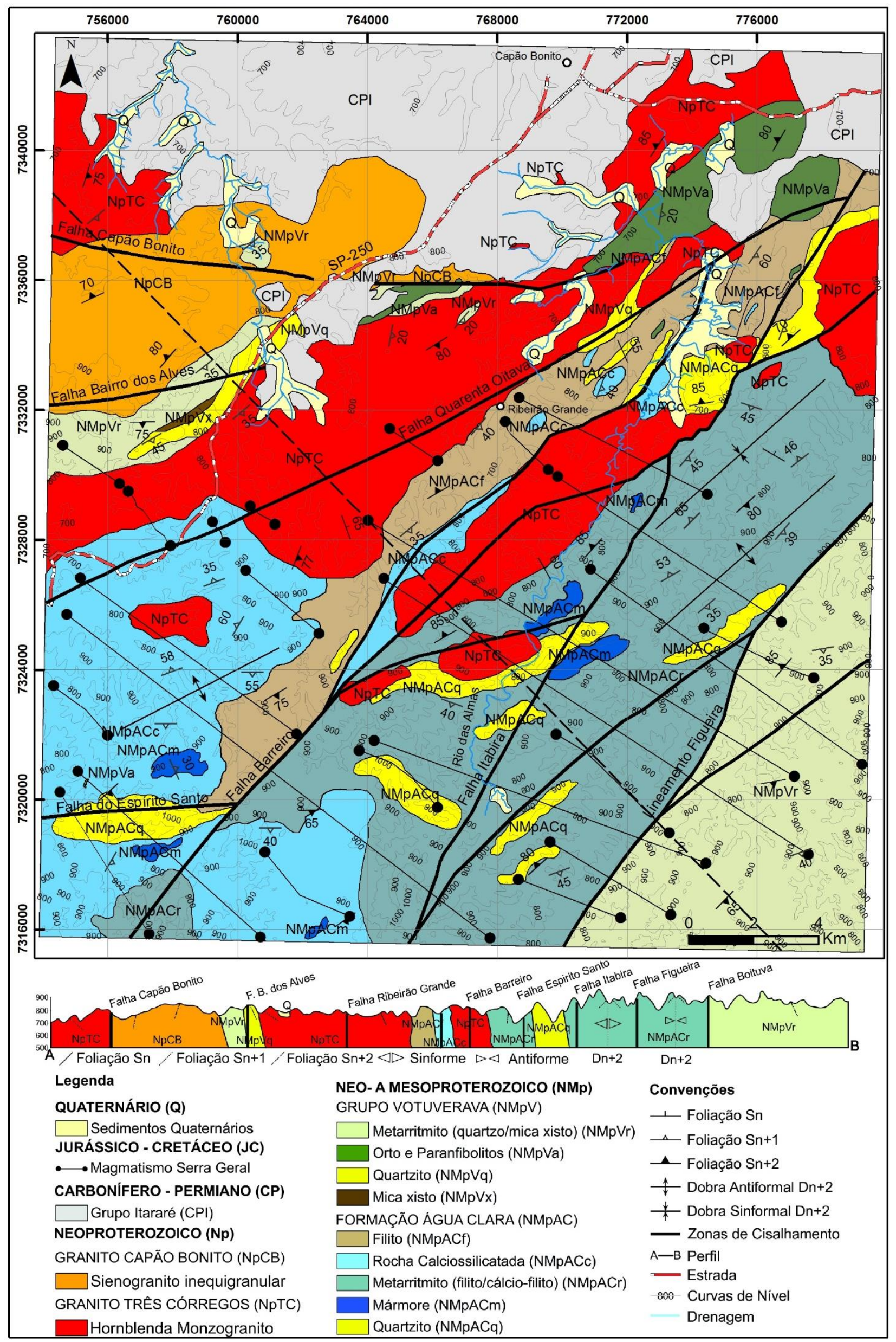

Figura 2 - Mapa Geológico da área da Folha Topográfica de Capão Bonito em 1:50.000. 
Esta unidade é composta por metassedimentos, com predominância de filito (Figura 3A) que gradaciona para muscovitabiotita xisto (Figura 3B) e para metarenito, além de constituir inúmeras vezes lentes ou camadas de metarritmito, que é representado por intercalações pelítica-psamíticas de espessuras variadas, ora com predominância de um termo ora de outro, além da expressiva e variada sequência de rochas calciossilicatadas e camadas de metacalcário e secundariamente por lentes de actinolita-carbonato xisto.

A sequência clástica é composta pelo predomínio dos termos mais argilosos, que se alternam em níveis de sericita filito, sericitagrafita filito, gradando para níveis mais enriquecidos em carbonatos com foliação bem marcante, predominantemente milonítica. Neste domínio, devido a intensa sobreposição de fases deformacionais aos litotipos mapeados, ocorre a ausência de estruturas primárias preservadas e muitas vezes não se permite caracterizar o bandamento composicional como $\mathrm{S}_{0}$, apesar da alternância dos litotipos sedimentares.

A rocha é composta de delgadas lâminas que apresentam quartzo e sericita, clorita e biotita em proporções variadas, originando porções grossas e finas a depender da relação entre esses dois minerais. A grafita e os carbonatos apresentam teores variados e com valores crescentes e gradacionais para cálcio-filito nas proximidades das rochas carbonáticas.

A variação composicional nos metassedimentos com deposição dominante dos pelitos e intercalações de lentes e camadas calcárias, sílticas e filíticas, indicam sucessão de ambientes químicos e detríticos. As rochas clásticas indicam um ambiente de águas calmas, com espessa lâmina d'água em plataforma distal. Níveis psamíticos intercalados podem ser indicativos de uma interdigitação com aporte de sedimentos terrígenos.

A unidade dos filitos é composta por rochas de coloração cinza, textura lepidoblástica e estrutura milonítica, constituídas predominantemente por sericita, em torno de $70 \%$, e quartzo subordinado (menos de 30\%). Nos grãos de quartzo maiores pode-se observar recristalização, estando alongados na foliação milonítica. Localmente ocorre grafita (10\%), minerais opacos, carbonatos e aumento na porcentagem de quartzo, além de biotita, que devido a granulação mais desenvolvida dos minerais micáceos, geram camadas xistosas.

Os quartzitos (Figura 3C) apresentam seus contatos transicionais com o metarritmito, na forma de bancos ou de corpos de pequenas espessuras, com geometria lenticular. São compostos basicamente por quartzo e pequenas quantidades de sericita, que se encontram paralelizadas à foliação. A granulometria também é variada, apresentando-se desde fina até grossa. Veios de quartzo leitoso sem orientação preferencial ocorrem com frequência em meio ao metarenito, sustentando as cristas de elevações no contato entre filito e metarritmito, apresentando espessura métricas, com direções NE-SW.

O quartzo perfaz $75 \%$ da composição total da rocha e, em menores quantidades, aparecem muscovita-sericita (20\%) tabulares ou em agregados policristalinos orientados, além de traços de minerais opacos, biotita, turmalina, clorita, apatita, titanita, epidoto e feldspato potássico (clastos).

O metarritmito (Figura 3D) caracteriza-se por estruturas rítmicas onde se alternam porções arenosas, siltosas e argilosas em diferentes espessuras e são compostos por faixas ricas em quartzos $(55 \%)$ estirado, com ou sem minerais opacos $(10 \%)$ associados e faixas de muscovita $(35 \%)$, orientadas gerando uma foliação, e traços de turmalina e leucoxênio. No geral, ocorre na forma de pacotes ou camadas com espessuras variáveis formadas por bandas centimétricas de filito, intercaladas em bandas mais espessas de metarenito. Observa-se um predomínio das camadas pelíticas em relação às psamíticas. Tais estruturas caracterizam processos turbidíticos em ambiente raso.

As rochas clásticas são representadas por intercalações pelítica-psamíticas de espessuras variadas, ora com predominância de um termo ora de outro (Figura 3E).

A sequência carbonática descrita apresenta termos carbonatados, tanto dolomíticos como calcíticos. O metacalcário calcítico é o principal litotipo desta sequência e apresenta estrutura foliada, por vezes levemente bandada quando se encontra em meio às zonas de cisalhamento. Essas bandas milimétricas são compostas basicamente por calcita e/ou quartzo. A granulometria é fina apresentando, porém, porções de granulometria grossas.

A geometria dos corpos de metacalcário é 
lenticular (Figura 3F), semelhante ao restante da sequência. Os contatos com as litologias adjacentes são geralmente bruscos, porém contatos transicionais também ocorrem. Frequentes são as camadas de metacalcário dolomítico que se encontram intercaladas no metacalcário calcítico, com espessuras decimétricas a métricas.

Quanto à mineralogia, a associação encontrada é basicamente constituída por carbonatos, quartzo e sericita, além da grafita. Essa litologia comumente aparece nas zonas de cisalhamento, assumindo estruturas boudinadas com inúmeros veios de quartzo e carbonatos de espessura milimétrica cortando a rocha.

O metacalcário puro e impuro define várias ocorrências e jazidas na área. A parte carbonática atinge até $80 \%$ do total. O calcário impuro difere quanto à mineralogia pela maior presença de quartzo $(37 \%)$ e pelo aumento da sericita e subordinadamente dolomita. Os cristais de calcita também se apresentam muito fragmentados, estirados e orientados segundo um bandamento provavelmente tectônico, paralelo a subparalelo à foliação milonítica gerando bandas com contatos irregulares entre os grãos.

As rochas calciossilicatadas e cálcio-filito bandado encontram-se em contato gradacional com as lentes de metacalcário ou apresentando boudinados entre a camadas de filito, apresentando estrutura foliada abandada e/ou maciça, textura lepidogranoblástica muito fina, intercalando-se em bandas centimétricas aos termos mais calcíticos e cortada por veios preenchidos por quartzo e carbonatos.

Como litotipos químicos são consideradas aqui todas as rochas da sequência carbonática que compreendem variedades de metacalcários calcíticos com $50 \%$ em média de $\mathrm{CaCO}_{3}$, cálciofilito e rochas calciossilicatadas. A presença de calcários resulta da precipitação tanto inorgânica como bioquímica preferencialmente em águas quentes e relativamente agitadas de zonas intermarés ou proximais, em ambientes de águas salgadas.

O Grupo Votuverava é representado por uma sequência metavulcanossedimentar caracterizada por uma sucessão de litotipos clásticos e raros químicos, além de intrusivas básicas, localizados entre duas grandes zonas de cisalhamento, a sul do Falhamento Bairro dos Alves e a norte da Falha Quarenta Oitava.
É representado predominantemente por filito, metarritmito e, localmente, xisto representado por uma granulação mais desenvolvida dos minerais micáceos, além de expressivas rochas metabásicas e raras e localizadas ocorrências de rochas calciossilicatadas. Esta unidade litológica corresponde ao topo das unidades metassedimentares da área e é interpretada como uma unidade turbidítica.

O filito de coloração avermelhada a arroxeada constitui o litotipo mais representativo da área. São compostos predominantemente por sericita (50$70 \%$ ) e quartzo (50-30\%), e gradam para metarritmito a partir de estruturas rítmicas onde se alternam porções psamo-pelíticas (arenosas, siltosas e argilosas) com diferentes espessuras ou colorações.

Os pacotes onde prevalecem metassedimentos argilosos ou silte-arenosos, cujas espessuras são destacadas, foram descritos respectivamente como lentes de filito, metassiltito e metarenito. Ocorre sob a forma de um pacote de baixo ângulo e direção NE-SW, definido por um bandamento composicional primário e apresentando uma feição planar (clivagem ardosiana) bem proeminente nestas rochas. Esta feição planar é vista ao longo de toda área, alternando-se apenas ao longo de zonas de cisalhamento, onde está feição passa a um bandamento tectônico verticalizado, podendo-se observar um bandamento composicional tectônico definido por lentes milimétricas a submilimétricas de diferentes composições e texturas.

A sequência química é representada por rochas calciossilicatadas que gradam para cálcio-filitos, dispostas em pequenas lentes de espessura centimétricas e não individualizadas (Figura 3G). As lentes de metarenito apresentam-se na forma de bancos ou de corpos geometricamente lenticulares de pequenas espessuras inseridos no metarritmito. São compostas por quartzo e pequenas quantidades de sericita de granulometria fina, além de raro feldspato e minerais opacos (Figura $3 \mathrm{H}$ ). Quando a recristalização dos grãos é mais intensa são denominados de quartzitos na Folha Guapiara (Vieira et al., 2018).

As ocorrências de veios de quartzo leitoso são frequentes em meio ao metarenito, ou em contato entre camadas de filito e metarritmito, sustentando as cristas das principais elevações, com direções NE-SW e E-W.

$\mathrm{Na}$ zona de cisalhamento a milonitização intensa ocasiona recristalização, silicificação e 
remobilizações de bancos arenosos e formação de veios de quartzo que sustentam o alinhamento de pequenas serras.

O muscovita xisto e muscovita-biotita xisto ocorrem na forma de lentes ou na forma de camadas geometricamente lenticulares de pequenas espessuras, numa faixa de direção NESW, constituindo gradações das rochas filíticas que são dominantes na área. São rochas de granulação média e de coloração esbranquiçada, constituídas por quartzo e muscovita, às vezes avermelhada pela presença biotita, com variações composicionais dadas por porções mais quartzosas e outras mais micáceas. Apresentam composições aproximadas de 50\% de quartzo, < $30 \%$ de muscovita, 5 a $30 \%$ de biotita e quantidades menos significativas de feldspato potássico, minerais opacos e zircão.

As rochas orto e paranfibolitos (Figura 3I) ocorrem na forma de pequenos corpos alongados com direção geral NE-SW, concordantes com a direção das camadas dos metassedimentos e localizam-se principalmente na porção nordeste da área.

Apresentam textura granonematoblástica, granulação média a grossa e um bandamento composicional incipiente formado pela maior concentração de plagioclásio em camadas milimétricas descontínuas, alternadas com camadas ricas em hornblenda. Paralelamente ao bandamento ocorre uma tênue foliação definida pela orientação dos agregados de hornblenda ou por minerais fibrosos de actinolita. As porcentagens de quartzo giram em torno de $5 \%$ ocorrendo também carbonato, clorita e epidoto. Compõem-se predominantemente por hornblenda e actinolita-tremolita, clorita e albita e menores porcentagens por quartzo, epidoto, carbonatos, titanita, rutilo e óxido de ferro.

Localmente, quando preservadas da deformação milonítica, nas rochas metassedimentares em contato com o Granito Capão Bonito são observadas texturas e mineralogias impostas pelo metamorfismo de contato com desenvolvimento de minerais em fácies albitaepidoto e hornblenda hornfels, além de serem comuns rochas de granulação mais grossa, como muscovita xisto e muscovita-biotita xisto.

As rochas do Complexo Três Córregos (Figura 3J) afloram em contato com o Granito Capão Bonito dispostas segundo a direção NESW. O contato noroeste do Granito Capão Bonito com estes granitóides se faz por meio de contato tectônico através da Falha de Capão Bonito pertencente a Zona de Cisalhamento Itapirapuã e o contato sul com a Falha Bairro do Alves da Zona de Cisalhamento Quarenta Oitava.

São sienogranito a monzogranito inequigranulares de granulação média a grossa a porfiríticos com fenocristais de aproximadamente 2 a $4 \mathrm{~cm}$, variando de coloração rósea a cinza. Apresenta textura granoblástica hipidiomórfica a intersticial granítica e estrutura muitas vezes foliada, possibilitando a identificação de uma foliação de baixo ângulo discreta, definida na orientação de fenocristais de feldspato potássico e dos minerais ferromagnesianos da matriz. Fácies pegmatíticas e presença de veios de quartzo cortando estas rochas também estão presentes.

Apresenta como minerais principais microclínio, oligoclásio e quartzo, além de quantidades variáveis de minerais ferromagnesianos (biotita e hornblenda), raros pseudomorfos de piroxênio e minerais acessórios constituídos por traços de titanita e leucoxênio, zircão e apatita. Os minerais secundários são sericita, clorita, calcita e epidoto, além de minerais opacos.

As rochas do Granito Capão Bonito afloram junto à borda da Bacia do Paraná e distribuem-se em um corpo alongado segundo a direção geral NE-SW. O corpo principal apresenta comprimento de $20 \mathrm{~km}$ e largura média de $5,5 \mathrm{~km}$, perfazendo uma área aproximada de $110 \mathrm{~km}^{2}$.

Os contatos norte e nordeste encontram-se encobertos parcialmente por rochas sedimentares do Grupo Itararé e por sedimentos recentes da Bacia do Paraná, expondo as rochas graníticas somente nas cabeceiras das principais drenagens.

As porções sul e sudoeste do corpo apresentamse mais íngremes e encontram-se mais dissecadas e erodidas com inúmeras exposições das litologias do maciço na forma de grandes matacões e lajedos parcialmente encobertos.

$\mathrm{Na}$ área de estudo as rochas do Granito Capão Bonito podem ser caracterizadas dominantemente por fácies porfirítica, equigranular e inequigranulares (Figura 3K), apresentando composições sieno- a monzograníticas e podendo variar de tonalidades róseas a acinzentadas, isotrópicos a levemente miloníticas e/ou cataclásticas nas regiões marginais do maciço ou em zona de fraturamento interna do maciço. Localmente podem ocorrer quantidades menores de quartzo monzodioritos escuros na forma de 
enclaves e as fácies tardias de sienogranitos equia inequigranulares a pegmatóides de menores expressões.

Os monzogranitos porfiríticos apresentam matriz de granulação média a grossa onde estão dispostos fenocristais de feldspato potássico de coloração rósea, numa proporção de 10 a $20 \%$ do total da rocha, com tamanhos de 1 a $3 \mathrm{~cm}$, podendo atingir porcentagens maiores que $30 \%$. $\mathrm{O}$ índice de coloração destes litotipos é basicamente leucocrático com variedades desde holo- até melagranitóides.

A mineralogia compreende microclínio (39$41 \%$ ), oligoclásio (20-22\%), quartzo (30-33\%), biotita e hornblenda (4-6\%), ao lado de minerais acessórios como zircão, apatita, titanita, allanita e minerais opacos. $\mathrm{O}$ microclínio são dominantemente pertíticos com formas subedrais de hábito tabular, porém ocorrem formas com bordas corroídas e ovaladas apresentando texturas rapakivi localizadas. Estas texturas podem ser contínuas ou descontínuas envolvendo os fenocristais.

Os sieno- a monzogranitos equigranulares róseos ocorrem localmente e com pequena expressão apresentando coloração rósea a branco, intrusivos nas fácies porfiríticas e com mineralogia semelhante, somente mais enriquecido em feldspato potássico e/ou quartzo.

As rochas são constituídas por quartzo, microclínio, oligoclásio, hornblenda e biotita parcialmente cloritizadas, apatita, titanita, zircão, minerais opacos primários e secundários $\mathrm{e}$ minerais de alteração como epidoto, carbonato, sericita, clorita e argilominerais.

O Grupo Itararé, na área de estudo, está localizado principalmente na porção norte, com a presença de arenitos mal selecionados, intercalados com argilitos e conglomerados basais.

Associado ao magmatismo básico da Formação Serra Geral (Figura 3L), ocorrem na área diques subverticais de espessuras métricas de diabásios de granulação fina a média, bem mais raramente de granulação grossa.

Estes corpos encontram-se controlados por um trend de direção principal NW-SE, que são correlatos aos diques que se encaixam na direção das juntas e enxames de diques do Lineamento Guapiara (NW-SE).

As coberturas sedimentares são constituídas por depósitos recentes formados por argilas, siltes, areias, cascalheiras, oriundos dos processos de erosão, transporte e posterior deposição em margens de rios, fundos de canal e planícies de inundação, além de sedimentos coluvionares expostos pouco expressivos no sopé das principais serranias.

\section{Interpretação Aerogeofísica}

A área da Folha Capão Bonito é constituída dominantemente por terrenos neoproterozoicos caracterizados por rochas metassedimentares e plutônicas ácidas alinhadas com o trend regional NE-SW, além de rochas sedimentares da Bacia do Paraná e os diques básicos associados ao vulcanismo da Bacia do Paraná.

A figura 4A apresenta os domínios tectônicos a partir da fusão do Mapa Geológico da Folha Topográfica de Capão Bonito com o modelo digital de relevo SRTM (Sutlle Radar Topographic Mission) e a figura 4B refere-se à localização da área de abrangência dos projetos inicialmente consultados para a realização do mapeamento.

A interpretação qualitativa dos dados aerogeofísicos, de magnetometria e gamaespectrometria teve como objetivo auxiliar os trabalhos da cartografia geológica da área. De modo geral, o estudo restringiu-se à análise de feições geofísicas, a partir dos contrastes laterais de propriedades físicas de minerais existentes nas litologias do terreno.

No mapa aeromagnetométrico (Figura 4E), nota-se uma característica comum a esse tipo de mapa, que é a bipolaridade, pela existência de valores positivos (em vermelho), os quais representam anomalias magnéticas do campo total geradas por corpos magnetizados, que corresponde ao exame de diques de diabásio do Arco de Ponta Grossa, associados aos valores negativos (em azul).

Percebe-se que há predominância de alinhamentos magnéticos associados aos diques de diabásio na direção NW-SE; porém, existe um alinhamento magnético perpendicular com direção NE-SW que corresponde ao alinhamento das rochas do Granito Capão Bonito

O mapa de gamaespectrometria (contagem total) (Figura 4D) permite a caracterização da geologia de superfície e representa a distribuição de diferentes rochas e solos, a partir de radioatividades acima do background, como granitoides e feições com radiação decrescente ou com baixas emissões de radiação gama. 


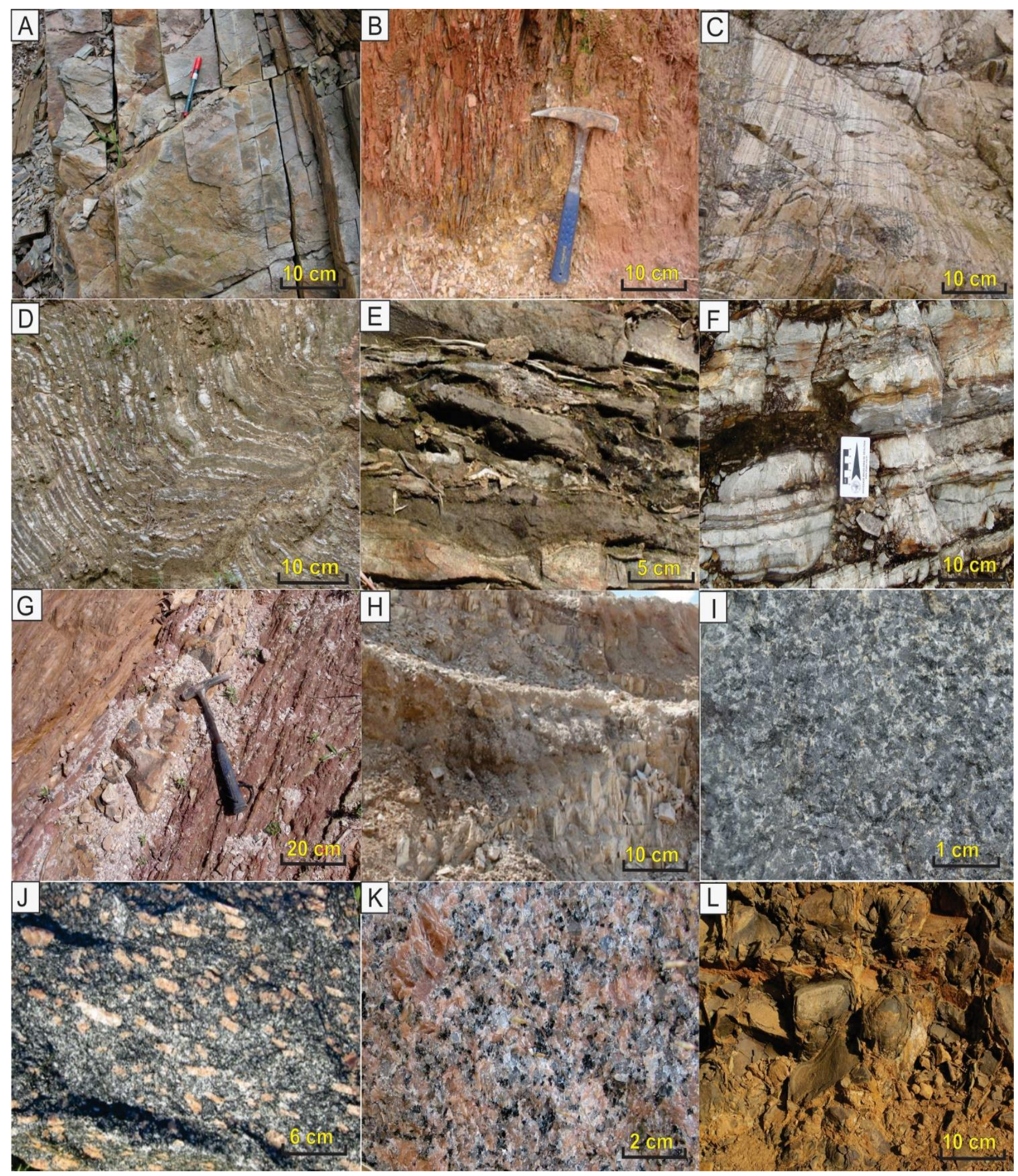

Figura 3 - Fotografias dos principais tipos de rochas que ocorrem na área da Folha Topográfica de Capão Bonito.

Legenda: A) Filito, B) Quartzo xisto, C) Metarritmito, D) Sericita quartzito, E) Quartzito, F) Quartzito alternando-se com filito, G) Filito com alternância de calciossilicatada, H) Mármore, I) Anfibolito granoblástico, J) Monzogranito Três Córregos, K) Sienogranito Capão Bonito, L) Diabásio Serra Geral.

Observa-se a concentração de elementos radiométricos muito elevada, principalmente com relação ao elemento potássio, observado pela tonalidade intensa em vermelho, possibilitando a caracterização das rochas de composição graníticas do Complexo Três
Córregos e Capão Bonito.

As regiões de concentração de radioelementos baixa são caracterizadas, na parte centro e sul da área pelas rochas metassedimentares e, no extremo norte pela ocorrência das rochas sedimentares da Bacia do Paraná. 

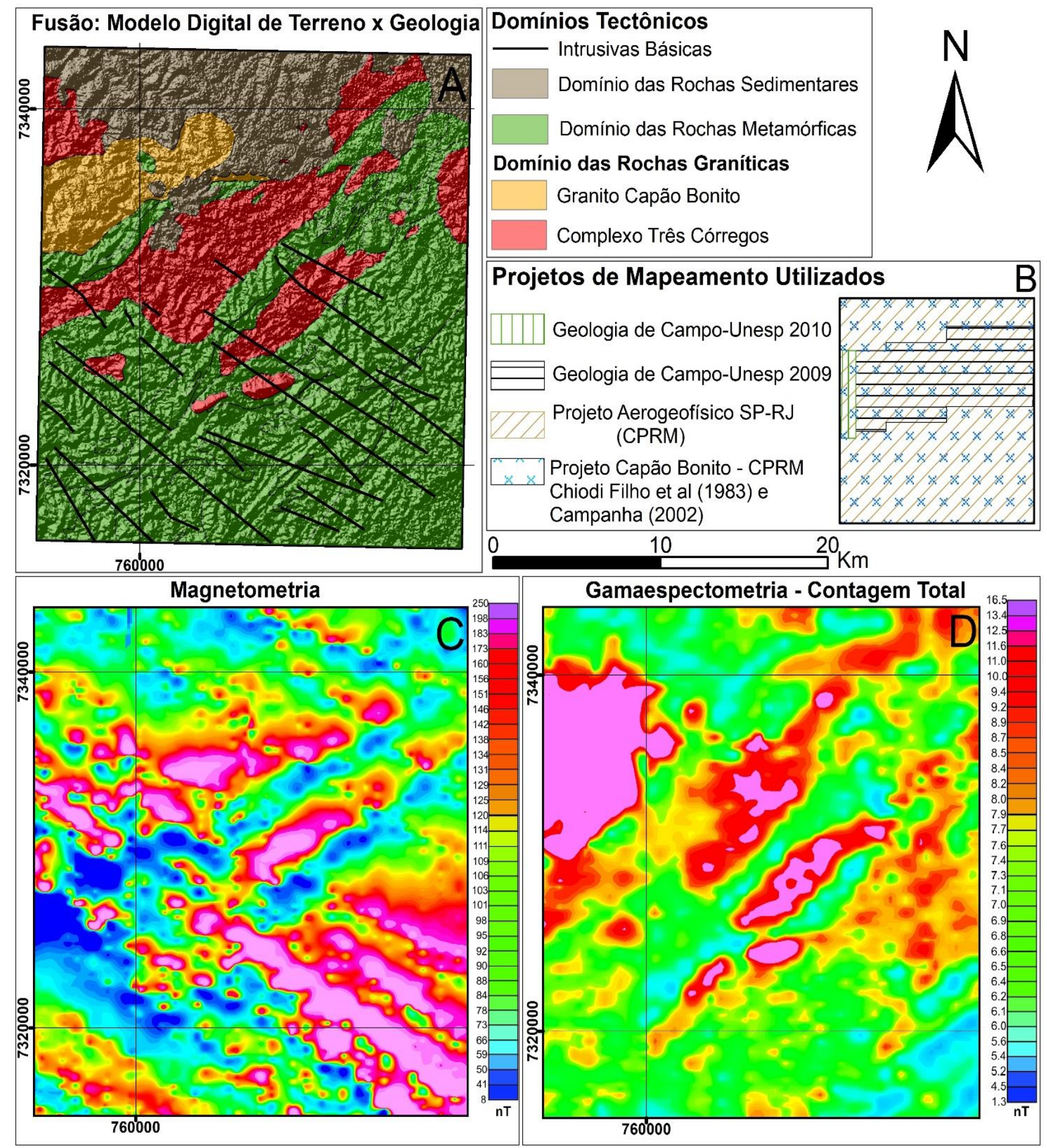

Figura 4 -A) Mapa dos Domínios Tectônicos com a fusão do Modelo Digital de Terreno versus Mapa Geológico. B) Mapa de localização e projetos consultados na Folha Topográfica de Capão Bonito. C) Mapa Aeromagnetométrico. D) Mapa de Gamaespectrometria - Contagem Total.

\section{Geologia Estrutural}

$\mathrm{O}$ quadro estrutural da área baseia-se nos dados do mapeamento geológico da Folha Topográfica de Capão Bonito em 1:50000 e áreas circunvizinhas, utilizando os trabalhos (Vieira, 2017; Vieira et al. 2018, 2018a) e é constituído pelo arranjo deformacional-metamórfico identificado principalmente nas rochas epimetamórficas meso-neoproterozoicas do Supergrupo Açungui e rochas granitoides.
O arcabouço estrutural é definido por três deformações principais, dominantemente de idade neoproterozoica, definidas como $D_{n}, D_{n+1}, D_{n+2}$, associadas aos eventos metamórficos $\mathrm{M}_{1}, \mathrm{M}_{2}$ e $\mathrm{M}_{3}$.

As estruturas primárias, devido aos intensos processos de transposição das foliações, não se encontram individualizadas e de fácil reconhecimento, mas sim paralelizadas a $S_{n}$ e $\mathrm{S}_{\mathrm{n}+1}$, definidas em alguns casos como $\mathrm{S}_{0} / / \mathrm{S}_{\mathrm{n}}$ e em outros como $\mathrm{S}_{0} / / \mathrm{S}_{\mathrm{n}} / / \mathrm{S}_{\mathrm{n}+1}$, e interpretadas na área 
como o flanco das dobras isoclinais $\mathrm{D}_{\mathrm{n}+1}$ ou das dobras abertas $\mathrm{D}_{\mathrm{n}+2}$, respectivamente.

Quando ocorre, de forma localizada, predomina somente o acamamento gradacional reliquiar $\left(\mathrm{S}_{0}\right)$, nas áreas menos deformadas, em que predominam uma foliação sub-horizontal das fases deformacionais de baixo ângulo $S_{n} / S_{n+1}$.

Nas zonas de cisalhamentos com foliação verticalizada penetrativa observam-se milonitos e filonitos e um bandamento tectônico, associados à deformação milonítica de alto ângulo $\mathrm{S}_{\mathrm{n}+2}$, com trend preferencial NE.

As fases progressivas $D_{n} / D_{n+1}$ encontram-se associadas às zonas de cavalgamento com formação de dobras isoclinais a recumbentes. $\mathrm{O}$ primeiro evento deformacional $\mathrm{D}_{\mathrm{n}}$ apresenta uma foliação plano-axial $S_{\mathrm{n}}$ de baixo a médio ângulo e atitude preferencial N30W/25NE (Figura 5A) representado por uma clivagem ardosiana ou xistosidade nos flancos dos dobramentos, dominantemente paralela à subparalela a $S_{0}$.

A fase deformacional $D_{n+1}$ é definida por redobramentos assimétricos gerando uma clivagem ardosiana ou de crenulação $S_{n+1}$, com atitude média de N55E/38SE (Figura 5B), representada como um padrão de guirlanda no estereograma, devido a fase $\mathrm{D}_{\mathrm{n}+2}$. Constitui a fase mais penetrativa e preservada em afloramentos em que dominam as foliações de baixo ângulo. Localmente, ocorrem as duas foliações $S_{n}$ e $S_{n+1}$, no entanto, quando paralelizadas nos flancos das dobras abertas é preservada apenas a foliação $\mathrm{S}_{\mathrm{n}+1}$ (Figura 4A, B).

Associado a esta fase tectônica dúctil $\mathrm{D}_{\mathrm{n}+1}$, ocorre a colocação e deformação das rochas sincolisionais do Complexo Três Córregos, vista principalmente na reorientação dos minerais máficos (biotita e hornblenda) e a geração de porfiroblastos nas auréolas de metamorfismo de contato desenvolvidas lateralmente aos corpos ígneos.

Esta relação estrutural, de uma foliação de baixo ângulo com corpos graníticos, ressalta o caráter sin- cinemático da colocação magmática ao evento tectônico $D_{n+1}$ do Supergrupo Açungui.

A deformação de caráter dúctil-rúptil e retrometamórfica $\mathrm{D}_{\mathrm{n}+2}$ (Figura 4C, D) ocorre associada à ascensão magmática tardia e a atual estruturação alongada do Granito Capão Bonito e a formação de dobras suaves a abertas (sinformais e antiformais), com flancos de $\mathrm{S}_{0} / / \mathrm{S}_{\mathrm{n}} / / \mathrm{S}_{\mathrm{n}+1}$ e plano axial de atitude preferencial
N50E/80SE (Figura 5C), que evolui gradativamente e localmente para falhas direcionais, apresentando foliação milonítica e/ou cataclásticas $\mathrm{S}_{\mathrm{n}+2}$, e mergulhos de alto ângulo tanto para SE, quanto para NW.

Nas zonas de cisalhamento, ocorre a geração de filonitos com acamamento tectônico que oblitera estruturas reliquiares das rochas encaixantes e ocorrem, além definir uma deformação milonítica, associada principalmente às bordas do corpo magmático.

No diagrama das juntas (Figura 5D) nota-se a formação de pelo menos dois máximos de concentração para os planos destas descontinuidades.

O máximo de maior concentração corresponde ao plano N20E/subvertical e o segundo máximo em concentração corresponde ao plano EW/ subvertical.

\section{Metamorfismo}

O quadro estrutural-metamórfico neoproterozoico é identificado principalmente nas rochas epimetamórficas e é evidenciado pelo registro de três fases deformacionais $D_{n}$ a $D_{n+2}$, além de um acamamento reliquiar $\mathrm{S}_{0}$, onde os eventos estruturais $S_{n}$ e $S_{n+1}$, de deformação de baixo a médio ângulo encontram-se associados à movimentos crustais convergentes, a partir das zonas de cavalgamento que se instalaram durante a fases iniciais da colisão e consequente espessamento de massas crustais, e encontram-se temporalmente correlacionados ao metamorfismo regional $\mathrm{M}_{1}$.

O metamorfismo de contato $\mathrm{M}_{2}$ está associado à colocação de rochas graníticas sintectônicas do Complexo Três Córregos no final da deformação $\mathrm{D}_{\mathrm{n}+1}$, e à colocação das rochas graníticas póstectônicas do Granito Capão Bonito associado a $\mathrm{D}_{\mathrm{n}+2}$.

O metamorfismo dinâmico e retrometamórfico $\mathrm{M}_{3}$ encontra-se correlacionado ao evento $\mathrm{D}_{\mathrm{n}+2}$, resultado de uma tectônica de descompressão e o consequente evento tectônico transcorrente final.

Esta área é recortada por diversas zonas de cisalhamento de alto ângulo de direção geral NESW, de movimentação direcional destral, que cortam uma trama tectônica de baixo ângulo e que apresentam um papel importante na caracterização estrutural e no zoneamento metamórfico das unidades na região de Capão Bonito.

Essas associações metamórficas estão intrudidas por corpos granitóides cálcio-alcalinos a alcalinos, deformadas ou não. 


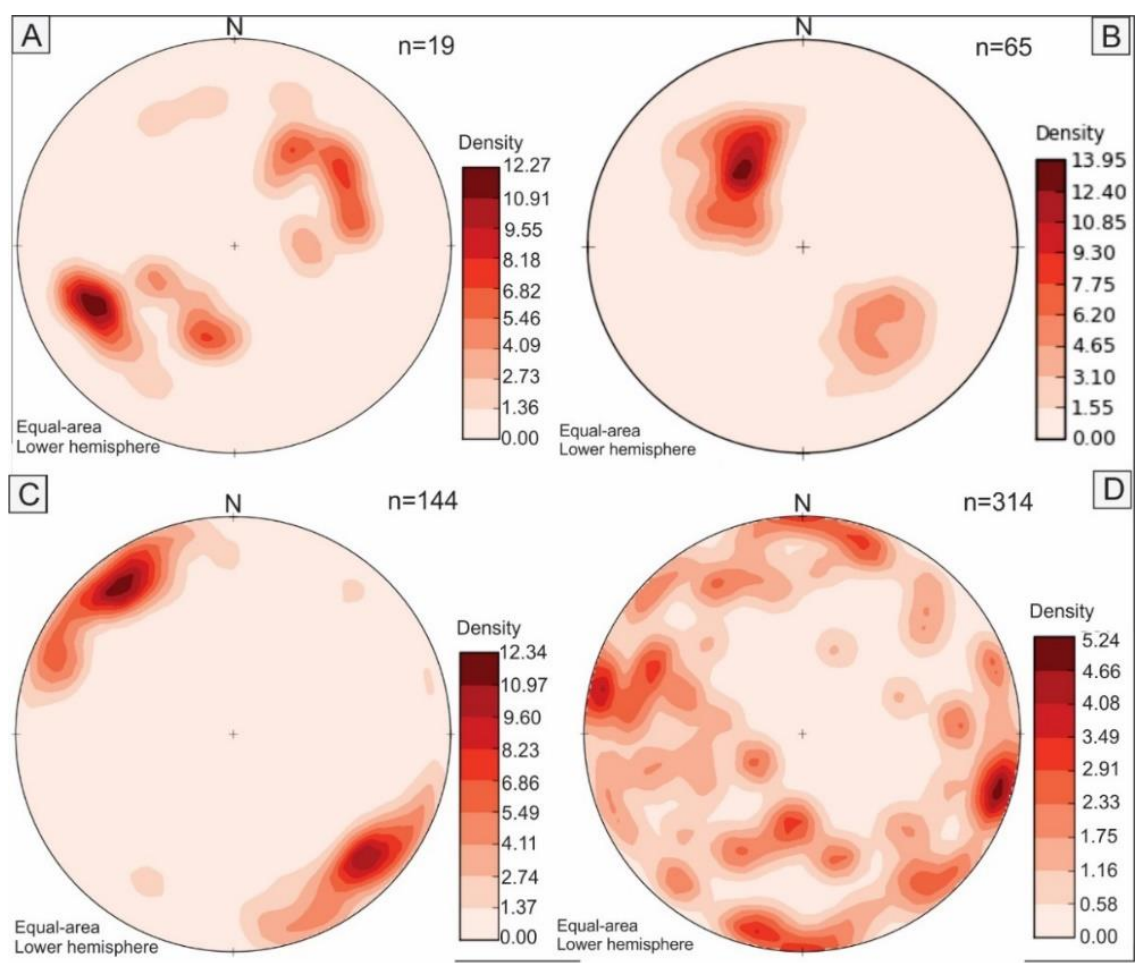

Figura 5 - Estereogramas do Domínio II. A) $S_{n}$ (N30W/25NE), B) $S_{n+1}$ (N55E/38SE), C) $S_{n+2}$ (N50E/80SE), D) Juntas (N20E/subvertical e EW/subvertical).
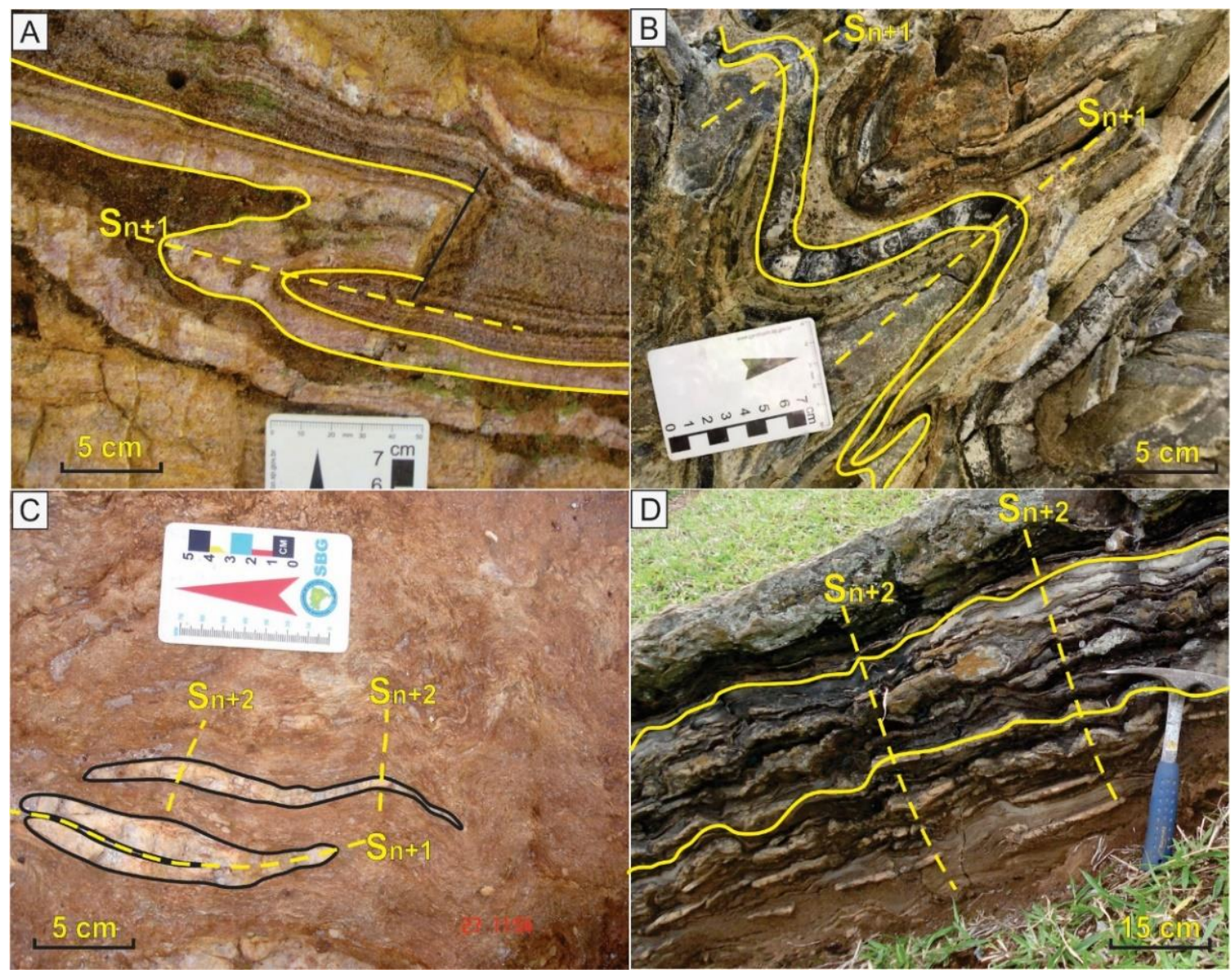

Figura 6 Superposição de deformação entre as foliações A, B) A foliação $S_{n}$ apresenta-se dobrada pelo evento $D_{n+1}$, com plano axial $S_{n+1}$. C, D) Padrão de dobramento aberto de $D_{n+2}$, com plano axial $S_{n+2}$ e flancos $S_{n+1}$

$\mathrm{O}$ evento metamórfico regional $M_{1}$ encontra- Foram descritos paragêneses principalmente nos se associado a $D_{n}$ e $D_{n+1}$ e é descrito nas rochas litotipos rochosos dominantes, o filito, que da sequência metavulcanossedimentar. É do tipo frequentemente transiciona para metarritmito, dinamotermal Barroviano, em fácies xisto-verde. nas rochas metacarbonáticas a calciossilicatadas 
e localmente nas ocorrências de rochas metabásicas.

É constituído pela paragênese composta por quartzo + albita + sericita + clorita + muscovita + biotita nos sedimentos terrígenos. A paragênese quartzo + albita + clorita + sericita, associada a $D_{n}$, é raramente preservada, mas é acompanhada comumente por recristalizações de biotita e muscovita, o que constitui o ápice metamórfico, contemporâneo à fase de deformação $\mathrm{D}_{\mathrm{n}+1}$, características visíveis nas rochas que apresentam $S_{n}$ paralelo $S_{n+1}$.

Quando estas encontram-se em ângulo, observa-se a presença de micas sericíticas e cloritas acompanhando o acamamento litológico $\mathrm{S}_{0}$ e dobradas em $D_{n}$. No plano axial $S_{n+1}$, encontra-se a reorientação de sericita + clorita da fase inicial, mas é comum a recristalização com a presença de biotita + muscovita, resultando em foliações de crenulação e constituindo a paragênese metamórfica em fácies xisto verdes médio a superior.

O quartzito, bem como os veios de quartzo presentes nos metapelitos, apresenta mecanismos de recristalização dinâmica do quartzo e, em algumas porções, elevado conteúdo em cristais de muscovita em sua forma mais fina. No metacalcário, o insipiente grau de marmorização e o tamanho desenvolvido dos cristais de calcita indicam que o metamorfismo não foi muito elevado.

As rochas calciossilicatadas são marcadas pela associação quartzo + albita + calcita + actinolita-tremolita + epidoto e, localmente, talco. Nas rochas metabásicas a paragênese é constituída por quartzo + albita + epidoto + hornblenda, que indicam fácies xisto verde superior.

$\mathrm{O}$ evento metamórfico de contato $M_{2}$ está associado a tectônica dúctil tardi $\mathrm{D}_{\mathrm{n}+1}$, o auge metamórfico, onde tem-se a colocação do corpo magmático do Complexo Três Córregos; e à fase $\mathrm{D}_{\mathrm{n}+2}$ de caráter rúptil-dúctil, com as rochas do Granito Capão Bonito, gerando uma auréola de metamorfismo de contato nas suas bordas. A geração dos porfiroblastos encontra-se controlada pelos planos de foliação $S_{n+1}$ e/ou $S_{n+2}$, ocorrendo a recristalização e desenvolvimento de minerais de contato sobre os do metamorfismo regional $\mathrm{M}_{1}$, que alcançam as fácies albita, hornblenda e localmente piroxênio hornfels. Esta paragênese é marcada pela presença principalmente de andaluzita, biotita, hornblenda, diopsídio e feldspato potássico principalmente na forma porfiroblastos que crescem tardiamente sobre a foliação $S_{n+1}$ e a formação de mica xistos de ocorrência lateral aos corpos ígneos.

As auréolas de metamorfismo termal apresentam-se parcialmente preservadas em função do menor grau de deformação imposto pelas zonas miloníticas nos contatos destes maciços, ou devido a menor intensidade das transformações minerais retrometamórficas impostas pelo metamorfismo.

$\mathrm{O}$ evento metamórfico dinâmico $e$ retrometamórfico $M_{3}$ ocorre regionalmente em faixas associados às zonas de cisalhamento de direção NE-SW.

$\mathrm{O}$ processo é intenso e vinculado à uma foliação milonítica e/ou cataclástica, com desenvolvimento de filonitos e um acamamento tectônico que oblitera estruturas reliquiares e as estruturas deformacionais mais antigas, ou mesmo atuam sobre os corpos graníticos, principalmente observado nas suas zonas marginais próximo aos contatos com as rochas metassedimentares e localmente nas regiões internas do corpo por falhamentos direcionais, sempre com direção paralelas às zonas de cisalhamento desenvolvidas no final da fase $D_{n+2}$. Este processo rúptil superpõe o conjunto das rochas, desestabilizando as paragêneses anteriores para condições de fácies xisto-verde baixa, a partir de transformações em sericita + clorita no filito, tremolita/actinolita + clorita + epidoto nas calciossilicatadas e tremolita/ actinolita + clorita + albita nas metabásicas.

\section{Evolução}

A relação dos processos sedimentares, tectônicos, metamórficos e magmáticos permite descrever a evolução da região, que se encontra associada a uma tectônica colisional, constituída inicialmente, em regime distensivo, a colocação de hot spots e o consequente adelgaçamento litosférico e rifteamento intracontinentais, a deriva de massas continentais e a formação de oceanos, associados com um magmatismo básico e sedimentação terrígena e química.

Basei et al. (2003); Weber et al. (2004) e Campanha et al. (2008) apresentam idades de sedimentação em torno de 1450-1500 Ma. Portanto, esta fase encontra-se relacionada à fragmentação do Supercontinente Rodínia e 
instalação da Tafrogênese no Mesoproterozoico (Figuras 7A, B).

Durante a Orogênese Brasiliana, em regime compressivo, ocorre a convergência de massas continentais e o consequente fechamento do oceano, orogênese, metamorfismo e magmatismo
(Figuras 7C a H), correlacionado à formação do Gondwana, com efeitos deformacionaismetamórficos e granitogênese francamente neoproterozoica, que atuaram na porção centro-sul da Província Mantiqueira, no Terreno Ocidental da Faixa Ribeira e no Terreno Apiaí.

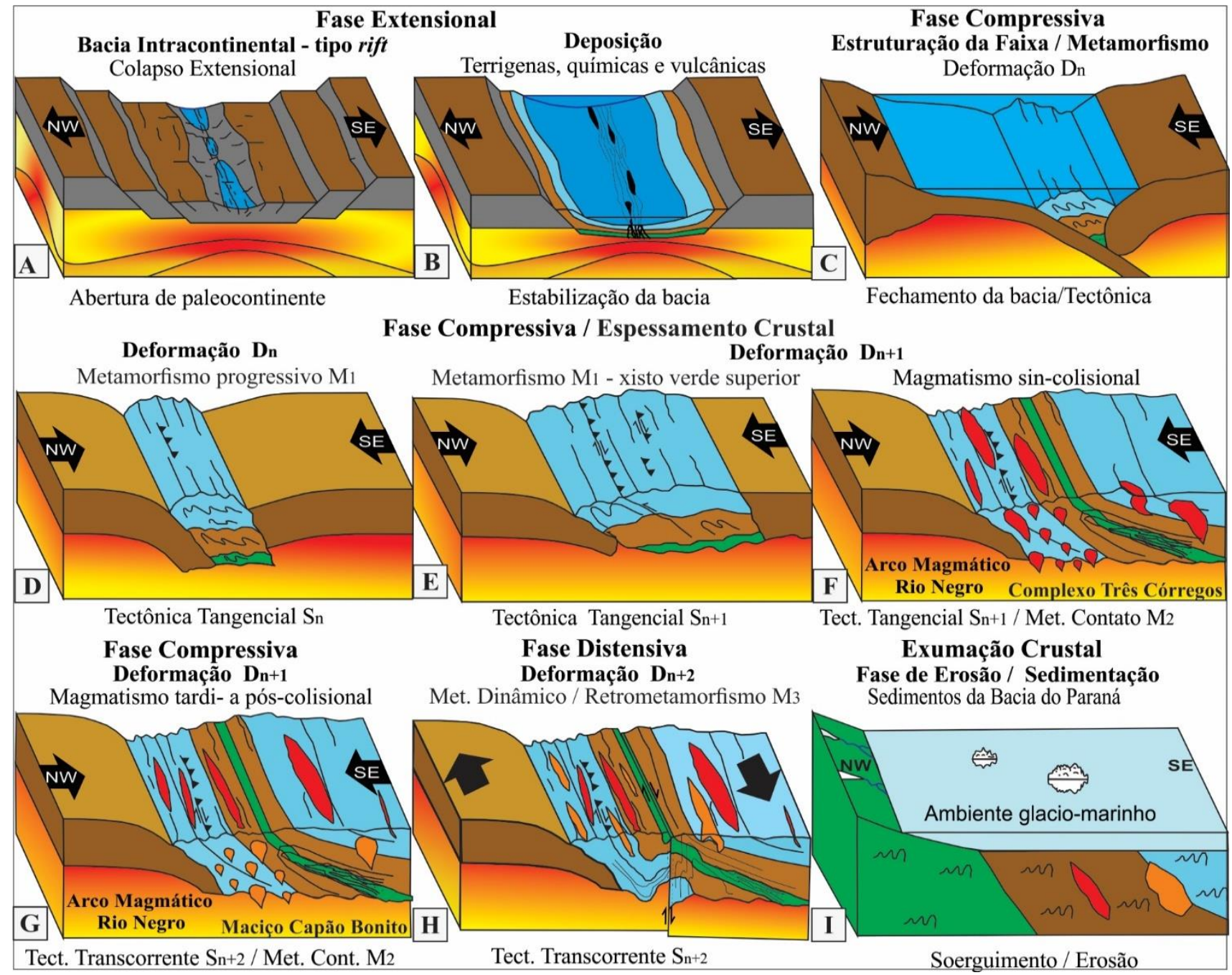

Figura 7 - Blocos diagrama da evolução do Terreno Apiaí. A) Fase extensional de rift intracontinental. B) Fase extensional com magmatismo básico-ultrabásico oceânico, deposição das sequências sedimentares do Supergrupo Açungui (Formação Água Clara e Grupo Votuverava). C, D, E) Fase compressiva, início de subducção em margem ativa e consequente espessamento crustal a partir da deformação tangencial $D_{n}, D_{n+1}$ de empurrão. F) Magmatismo sin-colisional (Complexo Três Córregos), G) Magmatismo pós-colisional (Granito Capão Bonito). H) Padrão de redobramento para a área associado a uma deformação final de natureza transcorrente e geração de $S_{n+2}$ de alto ângulo que atuam na forma atual do maciço granítico. I) Soerguimento, erosão e sedimentação das rochas do Grupo Itararé.

$\mathrm{Na}$ região foram observadas rochas pertencentes ao Supergrupo Açungui, associadas à Formação Água Clara e Grupo Votuverava, cujas idades variam de Callimiano (1500-1000 Ma) (Hackspacher et al., 2000; Weber et al., 2004; Campanha et al., 2008, 2015; Siga Junior et al., 2009, 2011), assim como rochas neoproterozoicas-eopaleozoicas (Complexo Três Córregos e Granito Capão Bonito) e rochas mesozoicas associadas as rochas terrígenas do Grupo Itararé, às rochas básicas pertencentes ao
Magmatismo Serra Geral e sedimentos quaternários.

O ambiente de deposição, das sequências metassedimentares mais antigas encontradas no Terreno Apiaí, seria uma plataforma marinha rasa associada a derrames de vulcânicas básicas toleíticas do tipo assoalho oceânico ou arcos de ilha, pouco diferenciado, sendo interpretado como uma margem continental passiva aberta para o oceano (Campanha, 2002).

Concomitante a deposição das rochas 
sedimentares coloca-se as rochas ultrabásicasbásicas na forma de diques ou intrusões que foram metamorfizadas e estão associadas a parte de um paleo-assoalho oceânico.

O registro evolutivo inicial da região refere-se à deposição das rochas sedimentares, posteriormentente metamorfizadas, pertencentes à Formação Água Clara (Figura 7B), compreendida no Supergrupo Açungui (Campanha, 1991; Campanha \& Sadowski, 1999), das quais reconheceu-se uma unidade basal metapelítica, constituída por muscovita xisto, quartzo-muscovita xisto e quartzito com biotita, sericita e clorita; e uma unidade superior dominante de composição carbonática, composta por mármore impuro e calciossilicatadas. Raramente, e de pequena expressão, são identificadas rochas metabásicas. Essa sequência litológica admite a interpretação do ambiente deposicional como sendo inicialmente marinho profundo, com formação de rochas pelíticas, gradando para um ambiente marinho raso, onde foram depositados calcário puro, impuro e quartzito.

O Grupo Votuverava (Figura 7B) é composto predominantemente por rochas da sequência metavulcanossedimentar, interpretada como uma sequência turbidítica de águas profundas (talude ou fossa). Ocorre ainda interdigitação de rochas vulcanossedimentares (metabasitos, rochas vulcanoclásticas e formações ferromanganesíferas), o que indica paleoambiente de águas profundas (Campanha \& Sadowski, 1999). Os metabasítos do Grupo Votuverava apresentam assinaturas geoquímicas distintas: basaltos toleíticos de arco de ilha, basaltos de dorsal meso-oceânica normais a levemente enriquecidos e basaltos de dorsal meso-oceânica enriquecidos (Faleiros et al., 2011).

A coexistência entre estes magmas de diferentes afinidades (arco vulcânico e fundo oceânico), e a ampla variação entre valores $\mathrm{Ti} / \mathrm{V}$ indicam um ambiente de bacia retroarco para o magmatismo básico deste grupo (Faleiros et al., 2011). Dados geocronológicos $\mathrm{U} / \mathrm{Pb}$ conferem idades callimianas $(1479 \pm 12 \mathrm{Ma}$ e $1510 \mathrm{Ma})$ (Perrotta et al., 2006), idades similares àquelas observadas na Formação Água Clara.

A evolução da região encontra-se associada inicialmente a uma tectônica colisional (Figura 7C, D), constituída por movimentos crustais convergentes, a partir de eventos tectônicos tangenciais e consequente espessamento de massas crustais. As rochas apresentam uma evolução estrutural do tipo polifásica, evidenciada pelo registro de três fases deformacionais $D_{n} \quad$ a $\quad D_{n+2}$, associadas ao metamorfismo $\mathrm{M}_{1}, \mathrm{M}_{2}, \mathrm{M}_{3}$. As deformações são registradas nos litotipos metassedimentares, em rochas metabásicas e, especificamente algumas fases, nos corpos graníticos. Durante a finalização do processo colisional, ocorreu uma tectônica transcorrente, definida principalmente pelas zonas de cisalhamento.

Associado a esta fase tectônica dúctil $\mathrm{D}_{\mathrm{n}+1}$, ápice metamórfico, ocorre a colocação e deformação das rochas granitoides sincolisionais do tipo I do Complexo Três Córregos (Figura 7E, F), formado em ambiente de arco magmático, sendo um magmatismo com contribuição de elementos mantélicos e diques tardios de composição granítica peraluminosa, provavelmente resultado de contaminação crustal.

Segundo Campanha \& Sadowski (1999), entre 700 e $600 \mathrm{Ma}$, a região de estudo apresentava-se em contexto de subducção, com geração de rochas granitóides do Tipo I, em ambiente de margem continental ativa do tipo andina, ou Cordilheirano, ou orogênico ou sin-colisionais e que constituem as fases magmáticas iniciais do Arco Magmático Rio Negro.

As idades U-Pb indicam que o Complexo Três Córregos se formou entre 615 e $605 \mathrm{Ma}$ (hornlenda-biotita granitos) e $600 \mathrm{Ma}$ nas intrusões isoladas tardias (Prazeres Filho et al., 2003).

$\mathrm{O}$ evento deformacional $\mathrm{D}_{\mathrm{n}+2}$ produz as últimas estruturas observadas na área que se relacionam ao evento tectonometamórfico do fim do Neoproterozoico, um estágio transcorrente e distensivo em que se associa as rochas do Granito Capão Bonito (Figura 7G, H).

O granito é consequência de um episódio intrusivo pós-colisional anorogênico, marcado por intrusão de plútons graníticos rasos datados entre 590 e $560 \mathrm{Ma}$ (idades U-Pb em zircão e Ar/Ar em biotita, segundo estudo de Prazeres Filho et al. (2003), que são extensão da Província Itu.

No Proterozoico, devido a erosão, ocorre a exumação do orógeno e em condições distensivas da formação da Bacia do Paraná, afloram na área os sedimentos terrígenos do Grupo Itararé (Figura $7 \mathrm{I})$.

No Cretáceo, ocorre a intrusão dos diques de 
diabásio do Magmatismo Serra Geral, que formam na área estruturas de direção NW-SE, como o Lineamento Guapiara. Por fim, a sedimentação quaternária.

\section{CONCLUSÕES}

$\mathrm{Na}$ região de Capão Bonito as principais unidades litoestratigráficas mapeadas são constituídas por metassedimentos da Formação Água Clara e do Grupo Votuverava de idade meso- a neoproterozoica, corpos graníticos neoproterozoicos do Complexo Três Córregos e do Granito Capão Bonito, rochas sedimentares do Grupo Itararé, intrusivas básicas do magmatismo Serra Geral e sedimentos quaternários.

O arranjo deformacional-metamórfico é identificado principalmente nas rochas epimetamórficas do Supergrupo Açungui e apresenta uma evolução estrutural marcada por três deformações principais atribuídas ao evento neoproterozoico.

Nas rochas do Supergrupo Açungui é possível a identificação de duas fases iniciais de baixo ângulo e uma de alto ângulo. Associada à tectônica dúctil $\mathrm{D}_{\mathrm{n}+1}$, ocorre o emplacement das rochas graníticas sin-colisionais do Complexo Três Córregos e a imposição de uma foliação $\mathrm{S}_{\mathrm{n}+1}$.

São biotita-hornblenda sienogranito a monzogranito inequigranulares de granulação média a grossa a porfiríticos com fenocristais de aproximadamente 3 a $4 \mathrm{~cm}$, variando de coloração rósea a cinza, apresentando discreta foliação de baixo ângulo.
As rochas neoproterozoicas do Granito Capão Bonito são constituídas dominantemente por sienogranitos vermelhos, holo- a leucocráticos com biotita e rara hornblenda, inequigranulares de granulação média a grossa a porfiríticos e isotrópicos a levemente cataclásticos.

Associada à fase deformacional $\mathrm{D}_{\mathrm{n}+2}$ ocorre a ascensão magmática e a atual estruturação alongada dos granitos pós-colisionais do Maciço Capão Bonito, com foliação milonítica e/ou cataclástica $\mathrm{S}_{\mathrm{n}+2}$ afetando principalmente as bordas do corpo, paralelas ao trend regional NE-SW.

$A$ fase $D_{n+2}$, de alto ângulo e direção preferencial NE/SW nas zonas miloníticas mascara as foliações antigas de baixo ângulo e, portanto, é a principal fase nestas áreas.

O metamorfismo regional progressivo é do tipo Barroviano definido como $\mathrm{M}_{1 / 2}$, sendo $\mathrm{M}_{2} \mathrm{o}$ ápice metamórfico na fácies xisto-verde alto; o metamorfismo de contato $\mathrm{M}_{2}$, com a formação local de hornfels e skarns encontra-se preservado em fácies albita e hornblenda hornfels, e o metamorfismo regional e dinâmico de caráter retrometamórfico $\mathrm{M}_{3}$, encontra-se em fácies xisto-verde baixa e é visualizado a partir das transformações minerais de hidratação e geração dos novos minerais em condições retrometamórficas.

\section{AGRADECIMENTOS}

Os autores externam seus agradecimentos ao CNPq pelo apoio do processo $\mathrm{n}^{\mathrm{o}}$ : 304614/2017-3.

\section{REFERÊNCIAS}

ALGARTE, J.P.; MARTINS, A.J.M.; MORGENTAL, A.; DAITX, E.C.; ANDRADE Jr, F.S.; BATOLLA Jr, F.; FERREIRA， F.J.F.; PINTO， G.G.; CUNHA， H.C.S.; DRUMOND, J.B.V., RODRIGUES, J.C.; YAMAMOTO, K.; KAEFER, L.Q.; CHIEREGATI, L.A.; PINHO FILHO, W.D.; ADDAS, W. Projeto Sudeste do Estado de São Paulo. Relatório Final. São Paulo: DNPM/CPRM, 1973

ALMEIDA, F.F.M. \& HASUI, Y. O Pré-Cambriano do Brasil. São Paulo, Blücher, 378p., 1984.

ALMEIDA, F.F.M. Novas ocorrências de fósseis no PréCambriano brasileiro. Anais da Academia Brasileira de Ciências, v. 29, n. 1, p. 63-72, 1957.

ALMEIDA, F.F.M. Origem e evolução da Plataforma Brasileira. Rio de Janeiro. Boletim DNPM/DGM, v. 241, 38p., 1967.

ALMEIDA, F.F.M.; HASUI, Y., BRITO-NEVES, B.B.; FUCK, R.A. Províncias estruturais brasileiras. SIMPÓSIO GEOLOGIA NORDESTE, 8, 1977, Campina Grande. Anais... Campina Grande: Sociedade Brasileira de Geologia, p. $363-$ 391, 1977.

ALMEIDA, F.F.M.; HASUI, Y.; BRITO-NEVES, B.B.B.; FUCK, R.A. Brazilian structural provinces: an introduction.
Earth Sciences Reviews, v. 17, p. 1-29, 1981a.

ALMEIDA, F.F.M.; HASUI, Y.; PONÇANO, W.L.; DANTAS, A.S.L.; CARNEIRO, C.D.R.; MELO, M.S.; BISTRICH, C.A. Mapa Geológico do estado de São Paulo em escala 1: 500.000. Nota explicativa. São Paulo, IPT, Monografias 6, v. 1, 126p., 1981.

BASEI, M.A.S.; SIGA JUNIOR, O.; KAULFUSS, G.A.; CORDEIRO, H.; NUTMAN, A.; SATO, K.; CURY, L.F.; PRAZERES FILHO, H.J.; PASSARELLI, C.R.; HARARA, O.M.; REIS NETO, J.M.; WEBER; W. Geochronology and isotope geochemistry of Votuverava and Perau Mesoproterozoic Basins, Southern Ribeira Belt, Brazil. In: SOUTH AMERICAN SYMPOSIUM ON ISOTOPE GEOLOGY (SHORT PAPERS), IV, 2003. São Paulo. Expanded Abstract... São Paulo.

BASEI, M.A.S.; SIGA JUNIOR, O.; MACHIAVELLI, A.; MANCINI, F. Evolução tectônica dos terrenos entre os cinturões Ribeira e Dom Feliciano (PR-SC). Revista Brasileira de Geociências, v. 22, p. 216-221, 1992.

BISTRICHI, C.A.; ALMEIDA, M.A.; STEIN, D.P. Geologia das folhas Barra do Chapéu (SG.22-X-B-I-4) e Araçaíba 
(SG.22-XF-II-3), estados de São Paulo e Paraná. São Paulo, Contrato IPT/ Pró-Minério, vol. 1, 104 p. (IPT. Relatório 22.150), 1985.

BISTRICHI, C.A.; CARNEIRO, C.D.R.; DANTAS, A.S.L.; PONÇANO, W.L.; CAMPANHA, G.A.C.; NAGATA, N.; ALMEIDA, M.A.; STEIN, D.P.; MELO, M.S.; CREMINI, O.A. Mapa geológico do Estado de São Paulo em 1: 500.000. IPT/Pró-Minério, São Paulo, v. 2, 1981.

BITTENCOURT, I.; FULFARO, V.J.; GIRARDI, V.A.V.; PETRI, S. Geologia da Folha de Capão Bonito, SP. In: CONGRESSO BRASILEIRO DE GEOLOGIA, 25, 1971, São Paulo. Boletim de Resumos...São Paulo: SBG, p. 94, 1971

BOLONINI, T.M. \& GODOY, A.M. Controle estrutural na lavra do Maciço Capão Bonito, SP, para utilização como rocha ornamental e para revestimento. In: SIMPÓSIO NACIONAL DE ESTUDOS TECTÔNICOS, XIII, 2011, Campinas. Anais.. Campinas: Sociedade Brasileira de Geologia, p. 512-515, 2011 BOLONINI, T.M. \& GODOY, A.M. Geologia e Geoquímica das rochas graníticas do Maciço Capão Bonito, SP. São Paulo, Geociências, v. 32, n. 3, p. 452-470, 2013.

BOLONINI, T.M. Geologia e Potencialidade do Granito "Vermelho Capão Bonito" (Sudoeste do Estado de São Paulo) como Rocha Ornamental. Rio Claro, 2011. 183p. Dissertação (Mestrado em Geociências), Instituto de Geociências e Ciências Exatas - Universidade Estadual Paulista.

BOLONINI, T.M.; GODOY, A.M.; SAAR, L.C.A. Geoquímica das Rochas do Maciço Capão Bonito, SP. In: CONGRESSO BRASILEIRO DE GEOQUÍMICA, XIII e SIMPÓSIO DE GEOQUÍMICA DOS PAISES DO MERCOSUL, III, 2011, Gramado. Anais...Gramado: Sociedade Brasileira de Geoquímica, p. 868-871, 2011.

CAMPANHA, G.A C.; FALEIROS, F.M.; BASEI, M.A.S.; TASSINARI, C.C.G.; NUTMAN, A.P.; VASCONCELOS, P.M. Geochemistry and age of mafic rocks from the Votuverava Group, southern Ribeira Belt, Brazil: Evidence for 1490Ma oceanic back-arc magmatism. Precambrian Research, v. 266 , p. 530-550, 2015.

CAMPANHA, G.A.C. \& SADOWSKI, G.R. Tectonics of the southern portion of the Ribeira Belt (Apiaí Domain). Precambrian Research, v. 98, p. 31-51, 1999.

CAMPANHA, G.A.C. O papel do sistema de zonas de cisalhamento transcorrentes na configuração da porção meridional da Faixa Ribeira. São Paulo, 2002. 105p. Tese (LivreDocência), Instituto de Geociências - Universidade de São Paulo.

CAMPANHA, G.A.C. Tectônica Proterozoica no Alto e Médio Vale do Ribeira, Estados de São Paulo e Paraná. São Paulo, 1991. 296p. Tese (Doutorado), Instituto de GeociênciasUniversidade de São Paulo.

CAMPANHA, G.A.C.; BASEI, M.A.S; TASSINARI, C.C.G.; NUTMAN, A.P.; FALEIROS, F.M. Constraining the age of the Iporanga Formation with shrimp U-Pb zircon: implications for possible ediacaran glaciation in the Ribeira belt, SE Brazil. Gondwana Research, v. 13, p. 117-125, 2008.

CAMPANHA, G.A.C.; BISTRICHI, C.A.; ALMEIDA, M.A. Considerações sobre a organização litoestratigráfica e evolução tectônica da faixa de dobramentos Apiaí. In: SIMPÓSIO SULBRASILEIRO DE GEOLOGIA, 3, 1987, Curitiba. Atas...Curitiba: SBG, v. 2, p. 725-742, 1987.

CHIODI FILHO, C.; TAKAHASHI, A.T.; SILVA, C.R.; FERREIRA, J.C.G. Projeto Capão Bonito. Relatório Final CPRM, v. I, Rio de Janeiro, 121p., 1983.

COMPANHIA DE PESQUISA DE RECURSOS MINERAIS Geologia e Recursos Minerais do Estado de São Paulo: Sistemas de Informações Geográficas (SIG). Brasília: MME, Programa Geologia do Brasil: Integração, Atualização e Difusão de Dados da Geologia do Brasil, Mapas Geológicos Estaduais. Escala 1:750000, CD-ROM, 2006.
CORDANI, U.G.; BITTENCOURT, I.; BETTENCOURT, J.S.; GOMES, C.B.; LELIS, H.S.; MELFI, A.J. Geologia da Folha de Guapiara, SP e PR. In: CONGRESSO BRASILEIRO DE GEOLOGIA, 25, 1971, São Paulo. Boletim de Resumos...São Paulo: Sociedade Brasileira de Geologia, p. 93, 1971.

CORDANI, U.G.; DELHAL, J.; LEDENT, O. Orogenèses superposeés dans le Précambrien du Brésil sud-oriental (États du Rio de Janeiro et de Minas Gerais). Revista Brasileira de Geociências, v. 3, n. 1, p. 1-22, 1973.

CORDANI, U.G.; SATO, K.; TEIXEIRA, W.; TASSINARI, C.C.G.; BASEI, M.A.S. Crustal evolution of the South American platform. In: CORDANI, U.G.; MILANI, E.J.; THOMAZ FILHO, A.; CAMPOS, D.A. (Eds.) Tectonic evolution of South America, Rio de Janeiro: p. 19- 40, 2000.

DANTAS, E.L.; HACKSPACHER, P.C.; FETTER, A.H.; SATO, K., PIMENTEL, M.M.; GODOY, A.M. ND Isotope Systematics Related to Proterozoic Evolution of the Central Ribeira Belt in the State of São Paulo, SE Brazil. Revista Brasileira de Geociências, v. 30, n. 1, p. 140-143, 2000.

DANTAS, E.L.; HACKSPACHER, P.C.; GODOY, A.M.; SATO, K.; PIMENTEL, M.M.; OLIVEIRA, M.A.F.; FETTER, A. Characterization of the generating sources of continental crust of the Ribeira Belt through isotopes of Nd in the state of São Paulo, SE of Brazil. In: SIMPÓSIO SUDAMERICANO DE GEOLOGIA ISOTÓPICA E SOUTH AMERICAN SYMPOSIUM ON ISOTOPE GEOLOGY, 2, 1999, Córdoba. Atas...Cordoba: Instituto de Geologia y Recursos Minerales, v. 1. p. 192-195.

FALEIROS, F.M. Evolução de Terrenos TectonoMetamórficos da Serrania do Ribeira e Planalto do Alto Turvo (SP, PR). São Paulo, 2008. 306p. Tese (Doutorado), Instituto de Geociências - Universidade de São Paulo.

FALEIROS, F.M.; CAMPANHA, G.A.C.; BELLO, R.M.S.; FUZIKAWA, K. Quartz recrystallization regimes, c-axis texture transitions and fluid inclusion re-equilibration in a prograde greenschist to amphibolite facies mylonite zone (Ribeira Shear Zone, SE Brazil). Tectonophysics, v. 485, p. 193-214, 2010.

FALEIROS, F.M.; FERRARI, V.C.; COSTA, V.S.; CAMPANHA, G.A.C. Geoquímica e petrogênese de metabasítos do grupo Votuverava (Terreno Apiaí, Cinturão Ribeira Meridional): evidências de uma bacia retro arco caliminiana. Geologia USP, Série Científica, v. 11, n. 2, p. 135-155, 2011.

FASSBINDER, E. A unidade Água Clara no contexto do Grupo Açungui: um modelo transpressivo de colisão oblíqua no Neoproterozoico paranaense. São Paulo, 1996. 207p. Tese (Doutorado), Instituto de Geociências Universidade de São Paulo.

FIORI, A.P. Evolução geológica da bacia Açungui. Boletim Paranaense de Geociências, v. 42, p. 7-27, 1994.

FIORI, A.P. Tectônica e estratigrafia do Grupo Açungui a norte de Curitiba. São Paulo, 1990. 261p. Tese (Livre Docência). Instituto de Geociências, Universidade de São Paulo, 1990

FIORI, A.P. Tectônica e estratigrafia do Grupo Açungui, PR. Boletim IG-USP. Série Científica, v. 23, p. 55-74, 1992.

FRASCÁ, M.H.B.O.; FIGUEIREDO, M.C.H.; ALMEIDA, M.A.; COUTINHO, J.M.V. Petrografia e geoquímica da Formação Água Clara, região de Araçaíba, SP. Geologia USP, Série Científica, v. 21, p. 73-92, 1990.

FUCK, R.A. Contribuição ao estudo das rochas graníticas do Estado do Paraná. Boletim Paranaense Geociências. v. 23/25, p. 183-221, 1967.

GODOY, A.M. Caracterização Faciológica, Petrográfica e Geoquímica dos Maciços Sorocaba e São Francisco, SP. São Paulo, 1989, 221p. Tese (Doutorado), Instituto de GeociênciasUniversidade de São Paulo. 
GODOY, A.M. Estudos Geológicos das Rochas Granitóides e Metamórficas e suas Aplicações como Rochas Ornamentais e de Revestimento. Rio Claro, 2003, 243p. Tese (Livre Docência), Instituto de Geociências e Ciências ExatasUniversidade Estadual Paulista.

GUIMARÃES, G.B. As rochas granitóides do Complexo Granítico Cunhaporanga, Paraná: Aspectos geológicos, geofísicos, geoquímicos e mineralógicos. São Paulo, 2000 230p. Tese (Doutorado), Instituto de Geociências-Universidade de São Paulo.

HACKSPACHER, P.C. \& GODOY, A.M. Vertical Displacement During Post-Colisional Escape Tectonic (Brasiliano Orogeny) of The Ribeira Belt, São Paulo, Brazil. Journal of African Earth Sciences. Elsevier Science Ltd., Africa do Sul, v. 29, n. 1, p. 25-32, 1999.

HACKSPACHER, P.C.; DANTAS, E.L.; SPOLADORE, A.; FETTER, A.H., OLIVEIRA, M.A.F. Evidence of Neoproterozoic back arc basin development in the Central Ribeira Belt, Southeastern Brazil new geochronological and geochemical constraints from São Roque Açungui groups. Revista Brasileira de Geociências, v. 30, n. 1, p. 110-114, 2000.

HASUI, Y. \& OLIVEIRA, M.A.F. Província Mantiqueira. Setor Central. In: ALMEIDA, F.F. \& HASUI, Y. (Eds). O PreCambriano do Brasil. São Paulo, p. 308-344, 1984.

HASUI, Y. A grande Colisão Pré-Cambriana do Sudeste brasileiro e a Estruturação Regional. São Paulo, UNESP, Geociências, v. 29, n. 2, p. 141-169, 2010.

HASUI, Y. Sistema Orogênico Mantiqueira. In: HASUI, Y., CARNEIRO, C.D.R., ALMEIDA, F.F.M.A., BARTORELLI, A. (org.) Geologia do Brasil. São Paulo, Beca, p. 331-372, 2012.

HASUI, Y.; CARNEIRO, C.D.R.; BISTRICHI, C.A. Os Granitos e Granitóides da Região de Dobramentos Sudeste nos Estados de São Paulo e Paraná. In: CONGRESSO BRASILEIRO DE GEOLOGIA, 30, 1978, Recife. Anais...Recife: Sociedade Brasileira de Geologia, p. 2579-2593,

HASUI, Y; DANTAS, A.S.L; CARNEIRO, C.D.R; BISTRICH, C.A. O embasamento Pré-Cambriano e Eo-Paleozóico em São Paulo. Mapa Geológico do Estado de São Paulo, Escala 1.500.000. São Paulo, SP, Brasil, 1: 12-45, 1981.

HEILBRON, M.; PEDROSA-SOARES, A.C.; CAMPOS NETO, M.C.; SILVA, L.C. TROUW, R.A.J.; JANASI, V.A. Província Mantiqueira. In: MANTESSO NETO, V., BARTORELLI, A., CARNEIRO, C.D.R., BRITO-NEVES, B.B. (Eds.) 2004. Geologia do Continente Sul-americano. São Paulo: Ed. Beca, p. 203-236, 2004

HEILBRON, M.; VALERIANO, C.M.; VALLADARES, C.S.; MACHADO, N.A Orogênese Brasiliana no segmento central da Faixa Ribeira, Brasil. Revista Brasileira de Geociências, v. 25, n. 4, p. 249-266, 1995.

HENNIES, W.T.; HASUI, Y.; PENALVA, F. O Falhamento Transcorrente de Taxaquara. In: CONGRESSO BRASILEIRO GEOLOGIA, 21, 1967, Curitiba. Anais...Curitiba: Sociedade Brasileira de Geologia, 1967. p. 159-168.

INSTITUTO DE PESQUISAS TECNOLÓGICAS (IPT). Catálogo de Rochas Ornamentais do Estado de São Paulo. São Paulo, 1990.

INSTITUTO GEOGRÁFIC0 GEOLÓGIC0 (IG). Mapa Geológico do Estado de São Paulo, em 1:1.000,000. São Paulo, 1974.

INSTITUTO GEOGRÁFICO GEOLÓGICO (IG). Mapa geológico do Estado de São Paulo, em 1:1.000.000, São Paulo, 1963.

JANASI, V.A. \& ULBRICH, H.H.G.J. Inventário Bibliográfico de Granitos do Estado de São Paulo. Boletim Instituto de Geociências. Publicação Especial, v. 11, 253p. 1992.

JANASI, V.A. \& ULBRICH, H.H.G.J. Late Proterozoic granitoid magmatism in the State of São Paulo, southeastern Brazil. Precambrian Resarch, v. 51, p. 351-374, 1991.
KOPS, P.T. Geologia das Formações Antinha, Votuverava e Água Clara à sudeste do Complexo Granítico Três Córregos, Estado do Paraná. Rio Claro, 1994. 132p. Dissertação (Mestrado), Instituto de Geociências-Universidade Estadual Paulista.

LEITE, J.Jr., HEAMAN, L.M., JANASI, V.A., MARTINS, L., CREASER, R.A. The late- to pos-orogenic transition in the Neoproterozoic Agudos Grandes Granite Batholith (Apia1' Domain, SE Brazil): Constraints from geology, mineralogy, and $\mathrm{U}-\mathrm{Pb}$ geochronology. Journal of South American Earth Sciences, v. 23, p. 193-212, 2007.

LEITE, R.J. Petrogênese e geocronologia U-Pb do magmatismo granítico tardi a pós-orogênico no Batólito Agudos Grandes-SP. São Paulo, 2003. 218p. Tese (Doutorado em Geociências), Instituto de Geociências, Universidade de São Paulo.

MELCHER, G.C.; CORDANI, U.G.; DAMASCENO, E.C.; GIRARDT, V.A.V.; GOMES, C.B., LELLI, S.H.S.; MELFI, A.J. Geologia das Rochas Pré-Cambrianas do Vale do Rio Ribeira de Iguape. In: CONGRESSO BRASILEIRO DE GEOLOGIA, 25, 1971, São Paulo. Boletim de Resumos...São Paulo: SBG, p. 193, 1971.

MELCHER, G.C.; GOMES, C.B.; CORDANI, U.G.; BETTENCOURT, J.S.; DAMACENO, E.C.; GIRARDI, V.A.V.; MELFI, A.J. Geologia e petrologia das rochas metamórficas e graníticas associadas do Vale do Rio Ribeira de Iguape, SP e PR. Revista Brasileira de Geologia, v. 3, n. 2, p. 97-123, 1973.

PASSARELLI, C.R.; BASEI, M.A.S.; CAMPOS NETO, M.C.; SIGA JÚNIOR, O.; PRAZERES FILHO, H.J. Geocronologia e Geologia Isotópica dos Terrenos Pré-Cambrianos da Porção Sul-Oriental do Estado de São Paulo. Geologia USP - Série Científica, v. 4, n. 1, p. 55- 74, 2004.

PERROTTA, M.M. Potencial aurífero de uma região do Vale do Ribeira, São Paulo, estimado por modelagem de dados geológicos, geoquímicos e geofísicos num sistema de informações georreferenciadas. São Paulo, 1996. 149p. Tese (Doutorado), Instituto de Geociências-Universidade de São Paulo.

PERROTTA, M.M., SALVADOR, E.D., LOPES, R.C., D'AGOSTINHO, L.Z., PERUFFO, N., GOMES, S.D., SACHS, L.L, MEIRA, V.T., GARCIA, M.G.M., LACERDA FILHO, J.V. Mapa Geológico do Estado de São Paulo, escala 1:750.000. Programa Geologia do Brasil-PGB, CPRM, São Paulo, 2005

PETRI, S. \& SUGUIO, K. Sobre os metassedimentos do grupo Açungui do extremo sul do estado de São Paulo. São Paulo. Secretaria de Serviços e Obras Públicas/Faculdade de Filosofia, Ciências e Letras da USP, p. 1-98, 1969.

PORSANI, J.L.; SAUCK, W.A.; SOUZA JUNIOR, A.O. GPR for mapping fractures and as guide for the extraction ornamental granite from a quarry: A case study from southern Brazil. Journal of Aplied Geophysics, v. 58, p. 177-187, 2005. PRAZERES FILHO, H.J.; HARARA, O.M.; BASEI, M.A.S.; PASSARELLI, C.R.; SIGA JUNIOR, O. Litoquímica, geocronologia $\mathrm{U}-\mathrm{Pb}$ e geologia isotópica $(\mathrm{Sr}-\mathrm{Nd}-\mathrm{Pb})$ das rochas graníticas dos batólitos Cunhaporanga e Três Córregos na porção sul do Cinturão Ribeira, Estado do Paraná. São Paulo, Boletim IG-USP/ Série Científica, v. 3, p. 51-70, 2003.

REIS NETO, J.M. Faixa Itaiacoca: registro de uma colisão entre dois blocos continentais no Neoproterozoico. São Paulo, 1994, 296p. Tese (Doutorado), Instituto de Geociências - Universidade de São Paulo.

SALAZAR, C.A.; RODRIGUES, S.W.O.; VELÁSQUEZ, M.E.; ARCHANJO, C.J.; BRUMATTI, M. Geoquímica e Trama do Granito Capão Bonito: Domínio Apiaí, Faixa Ribeira (SP). In: CONGRESSO BRASILEIRO DE GEOQUÍMICA, XIII e SIMPÓSIO DE GEOQUÍMICA DOS PAISES DO 
MERCOSUL, III, 2011, Gramado. Anais... Gramado: Sociedade Brasileira de Geoquímica, p. 657-660, 2011.

SALLUN FILHO, W.; FAIRCHILD, T.R.; ALMEIDA, F.F.M.; FRANCA, D.R. Estromatólitos de Nova Campina e Itapeva, SP - Primeiros estromatólitos descritos na América do Sul. Sítios Geológicos e Paleontológicos do Brasil, v. 3, p. 1- 16, 2010.

SANTOS, T.M.B.; TASSINARI, C.C.G; FONSECA, P.E. Diachronic collision, slab break-off and long-term high thermal flux in the Brasiliano-Pan-African orogeny: Implications for the geodynamic evolution of the Mantiqueira Province. Precambrian Research, v. 260, p. 1-22, 2015.

SIGA JUNIOR, O. Domínios tectônicos do Sudeste do Paraná e nordeste de Santa Catarina: geocronologia e evolução crustal. São Paulo 1995. 212p. Tese (Doutorado), Instituto de Geociências - Universidade de São Paulo.

SIGA JUNIOR, O.; BASEI, M.A.S.; PASSARELLI, C.R.; SATO, K.; CURY, L.F.; MCREATH, I. Lower and Upper Neoproterozoic magmatic records in Itaiacoca Belt (ParanáBrazil): zircon ages and lithostratigraphy studies. Gondwana Research, v. 15, p. 197-208, 2009.

SIGA JUNIOR, O.; BASEI, M.A.S.; SATO, K.; PASSARELLI, C.R.; NUTMAN, A.; MCREATH, I.; PRAZERES FILHO, H.J. Calymmian (1.50-1.45 Ga) magmatic records in Votuverava and Perau sequences south-southeastern Brazil: zircon ages and $\mathrm{Nd}-\mathrm{Sr}$ isotopic geochemistry. Journal of South American Earth Sciences, v. 32, p. 301-308, 2011.

SOARES, P.C. Sequências tectonossedimentares e tectônica deformadora no centro-oeste do escudo paranaense. In: SIMPÓSIO SUL-BRASILEIRO DE GEOLOGIA, 3, 1987, Curitiba. Atas...Curitiba: Sociedade Brasileira de Geologia, v. 2, p. 743- 771, 1987.

SOARES, P.C. Tectônica colisional em torno do bloco Paraná, Brasil. In: CONGRESSO LATINO-AMERICANO DE GEOLOGIA, 7, 1988, Belém. Anais... Belém: Sociedade Brasileira de Geologia, v. 1, p. 63-79, 1988.

SOUZA JÚNIOR, A.O. \& PORSANI, J.L. Localização de fraturas em rochas graníticas, no município de Capão BonitoSP, Brasil. São Paulo, Revista Brasileira de Geofísica, v. 20, p. 123-128, 2003.

SOUZA, A.P. Mapa geológico na escala 1:50.000 e esboço da evolução tectônica e sedimentar do Grupo Itaiacoca nas folhas Barra do Chapéu e Ouro Verde-SP/PR. São Paulo, 1990. 200p. Dissertação (Mestrado), Instituto de GeociênciasUniversidade de São Paulo.

SPINELLI, F.P. \& GOMES, C.B. A ocorrência alcalina de Cananéia, litoral Sul do Estado de São Paulo: geologia e geocronologia. Geologia USP. Série Científica, v. 8, n 2, p. 53- 64, 2008.
TASSINARI, C.C.G. As Idades das Rochas e dos Eventos Metamórficos da Porção SE do Estado de São Paulo e sua Evolução Crustal. São Paulo, 1988. 236p. Tese (Doutorado), Instituto de Geociências - Universidade de São Paulo.

TASSINARI, C.C.G.; BARBOUR, A.P.; DAITX, E.C.; SATO. $\mathrm{K}$. Aplicação dos isótopos de $\mathrm{Pb}-\mathrm{Sr}$ na determinação da natureza das fontes das mineralizações de chumbo do Vale do Ribeira - SP e PR. In: CONGRESSO BRASILEIRO DE GEOLOGIA, 36, 1990, Natal. Anais... Natal: Sociedade Brasileira de Geologia, n. 3, p. 1254-1266, 1990.

VIEIRA, O.A.R.P. Geologia da Folha Guapiara 1:50000 (SG22-X-B-II-2). Rio Claro, 2017. 145p. Dissertação (Mestrado), Instituto de Geociências e Ciências Exatas-Universidade Estadual Paulista.

VIEIRA, O.A.R.P.; GODOY, A.M.; HACKSPACHER, P.C.; LEITE JUNIOR, W.B. Contexto Estrutural da Área da Folha Topográfica Guapiara. São Paulo, UNESP, Geociências, v. 37 , n. 3, p. 505-521, 2018a.

VIEIRA, O.A.R.P.; GODOY, A.M.; LEITE JUNIOR, W.B.; HACKSPACHER, P.C. Geologia da Folha Topográfica Guapiara na escala 1:50.000. São Paulo, UNESP, Geociências, v. 37, n. 2, p. 263-277, 2018.

VLACH, S.R.F.; JANASI, V.A.; VASCONCELLOS, A.C.B.C. The Itú Belt: associated calc alkaline and aluminous a-type late Brasiliano granitoids in the states of São Paulo and Paraná, southern Brazil. In: CONGRESSO BRASILEIRA DE GEOLOGIA, 36, 1990, Natal. Anais...Natal: Sociedade Brasileira de Geologia, v. 4, p. 1700-1711, 1990.

WEBER, W.; SIGA JÚNIOR, O.; SATO, K.; REIS NETO, J.M.; BASEI, M.A.S.; NUTMAN, A.P. A Formação Água Clara na região de Araçaíba - SP: registro de uma bacia mesoproterozoica. Geologia USP, Série Científica, v. 4, p. 101-110, 2004.

WERNICK, E. Arc-related Rapakivi Granites from the Ribeira Fold Belt, SE Brazil. Revista Brasileira de Geociências, v. 30, n. 1, p. 20-24, 2000.

WERNICK, E. The Pluriserial Ribeira Magmatic System 590, SE/S Brazil and Uruguay. Revista Brasileira de Geociências, São Paulo, SP, v. 28, n. 4, p. 533-542, 1998.

WERNICK, E.; GALEMBECK, T.M.B.; GODOY, A.M.; HERMANN, P.K. Geochemical variability of the Rapakivi Itu Province, State of São Paulo, SE Brazil. Anais da Academia Brasileira de Ciências, v. 69, n. 3, p. 395-413, 1997.

Submetido em 10 de julho de 2017 Aceito em 12 de novembro de 2018 